\title{
Arqueologia e história indígena no Pantanal
}

\author{
EDUARDO BESPALEZ ${ }^{I}$
}

\section{Introdução}

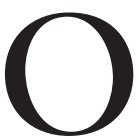

ARTIGO em mãos apresenta uma síntese dos dados arqueológicos sobre o Pantanal e o seu entorno, principalmente em se tratando dos estados do Mato Grosso e do Mato Grosso do Sul, na perspectiva da arqueologia enquanto história indígena de longa duração (Brochado, 1984; Eremites de Oliveira, 2003; Heckenberger, 2005; Hodder, 1987; Neves, 2000; Noelli, 1999; Wüst, 1990). Entre outras premissas, como a adoção de uma postura crítica em relação aos modelos teóricos tradicionais, carregados de preconceitos colonialistas herdados do positivismo, do evolucionismo social e do determinismo ambiental, e a busca pela interdisciplinaridade, sobretudo entre os campos da antropologia four field, o ponto de vista tomado pressupõe, sem prejuízo dos focos paleoetnográficos, um interesse nos processos de continuidade e mudança histórica e cultural de longa e longuíssima duração, interpretados através da análise das variáveis espaciais, temporais e materiais dos contextos arqueológicos.

O Pantanal está localizado no centro da América do Sul, entremeio às fronteiras do Brasil, da Bolívia e do Paraguai, por um lado, e do Mato Grosso e do Mato Grosso do Sul, por outro, entre o Planalto Central, a Amazônia e o Chaco (Figura 1). Constituído por vários pantanais, alagados sazonalmente pelo Paraguai e pelos tributários do seu alto curso, trata-se da maior planície interiorana do planeta, e, devido às suas peculiaridades fisiográficas e ecológicas, consiste em uma das principais áreas de preservação ambiental da atualidade (Ab’Sáber, 2006; Magalhães, 1992; Brasil - Radambrasil, 1982; Seplan, 1990).

A diversidade cultural da região, apesar de não muito noticiada, é tão notável quanto a ambiental, tanto que o Pantanal e o seu entorno têm sido compreendidos, do ponto de vista etnográfico, como um mosaico e/ou como uma encruzilhada de povos e área de fusão (Carvalho, 1992; Métraux, 1946; Ribeiro, 1986). Com efeito, mesmo com os impactos do colonialismo, a região ainda continua sendo ocupada por populações indígenas portadoras de matrizes culturais distintas, originadas no Chaco, no Brasil Central e na Amazônia, a exemplo, respectivamente, dos Kadiwéu e dos Guaikuru, falantes de línguas da família Mbayá-Guaikuru; dos Camba, da família linguística Camba; dos Bororo, Umutina, Ofayé e Guató, com famílias inseridas no tronco Macro-Jê, se bem que ainda haja dúvidas em relação à vinculação da língua Guató ao Macro-Jê (Ribeiro, 2006, p.422); dos Terena, Laiana e Kinikinao, de línguas Chané- 
-Guaná, da família Aruak; e dos Guarani e Kaiowá, falantes de línguas Guarani, da família Tupi-Guarani, do tronco Tupi (Martins, 2002a; Eremites de Oliveira, 2001a, 2012).

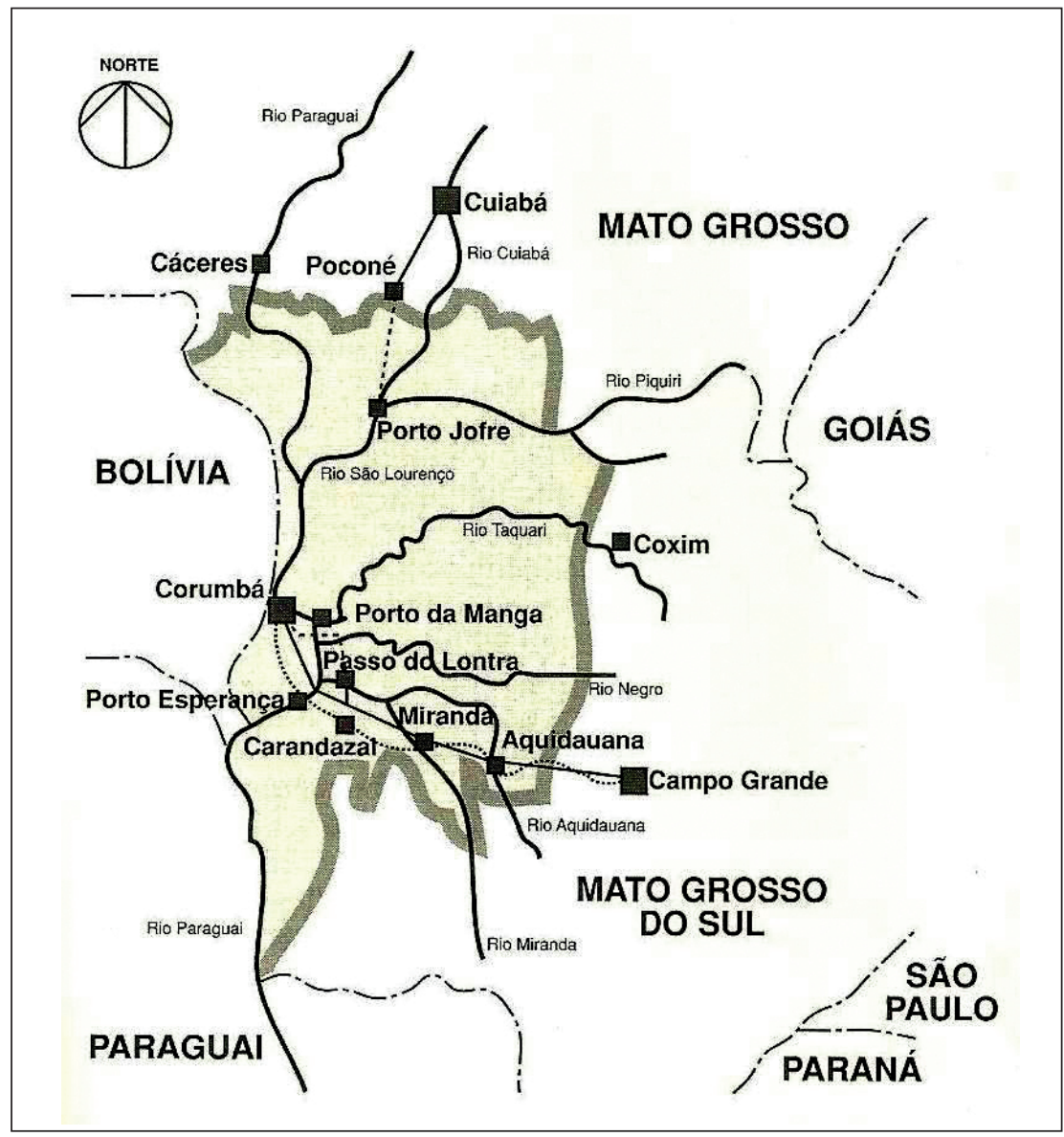

Figura 1 - Mapa de localização do Pantanal (Magalhães, 1992, p.9).

Apesar dos riscos da associação entre cultura material e etnia (Eremites de Oliveira, 2004; Jones, 1997), não só é obvio que os grupos étnicos atuais descendem das populações indígenas que se estabeleceram na região tanto antes quanto depois da chegada dos conquistadores e colonizadores de origem europeia, como ainda é evidente que a variabilidade dos registros arqueológicos pode contribuir com a compreensão da história cultural no Pantanal (Anthony, 2007). Assim, com o objetivo de proporcionar um panorama arqueológico da dinâmica da ocupação indígena regional, o texto a seguir começa com o estabelecimento dos povos caçadores-coletores-pescadores nas escarpas circum-adjacentes e nos planaltos residuais, entre o Pleistoceno e o Holoceno Médio; continua com a incorporação da cerâmica e a ocupação das planícies inundáveis, a partir de três mil anos atrás (ap); e termina com o assentamento de populações 
agricultoras, portadoras de matrizes culturais originadas no Brasil Central e na Amazônia, nos planaltos e nos piemontes da região, entre três e dois mil anos ap, e com os impactos causados pelo colonialismo na configuração etnográfica encontrada pelos europeus.

\section{O estabelecimento da ocupação indígena no Pantanal e entorno}

As investigações arqueológicas sugerem que a trajetória histórica da ocupação indígena regional pode ter se iniciado no final do período Pleistocênico, com o estabelecimento de grupos paleoíndios nas áreas de refúgio ecológico em torno do Pantanal (Ab'Sáber, 2006; Eremites de Oliveira, 1999; Eremites de Oliveira; Viana, 1999-2000). Em Santa Elina, um abrigo sob rocha com arte rupestre situado no sopé da serra das Araras, no município de Jangada (MT), foram obtidas datações arqueológicas com mais de vinte mil anos antes do presente (ap), em níveis estratigráficos em que os vestígios da cultura material estavam associados a restos faunísticos de animais extintos da megafauna (Vilhena-Vialou, 2005). As pesquisas realizadas no Abrigo do Sol, localizado no alto curso do rio Guaporé, igualmente remetem a ocupação indígena no Mato Grosso ao Pleistoceno, com datas que alcançam até dezenove mil anos (Miller, 1983).

$\mathrm{Na}$ transição do Pleistoceno-Holoceno, ou seja, no período entre doze e oito mil anos atrás, as transformações ecológicas ocasionadas com a crescente tropicalização do meio favoreceram o estabelecimento de diversas populações caçadoras-coletoras na região. Além de Santa Elina, contextos arqueológicos datados desse período foram pesquisados em outras regiões em torno do Pantanal, não só no Mato Grosso, mas também no Mato Grosso do Sul. No território dos índios Bororo, no sudeste de Mato Grosso (Wüst; Vaz, 1998), e no alto curso do rio Sucuriú, no nordeste de Mato Grosso do Sul (Martins; Kashimoto, 2012; Schmitz, 1998), tais contextos, detectados em abrigos rupestres, foram atribuídos à Tradição Itaparica. Principalmente concebida por conta dos aspectos tecnotipológicos da indústria lítica, onde se destacam artefatos plano-convexos com talhes e retoques unifaciais, os sítios Itaparica, também encontrados a céu aberto, foram associados com um horizonte bastante amplo de povos caçadores-coletores estabelecidos nos planaltos do centro-oeste, sudeste, nordeste e norte do Brasil (Bueno, 2007; Etchevarne, 1999-2000; Prous, 1992, 1999; Schmitz, 1999a; Silva, 1992).

$\mathrm{Na}$ região centro-oeste, principalmente em Goiás, admite-se ainda outro horizonte caçador-coletor, denominado Tradição Serranópolis, datada do Holoceno Inicial (Schmitz, 1999a). Caracterizada a partir de conjuntos artefatuais formados por uma indústria lítica expediente, por vezes detectada nos mesmos sítios em que se encontram vestígios atribuídos à Tradição Itaparica, a ocorrência de vestígios associados à Tradição Serranópolis ainda não se encontra definitivamente constatada em Mato Grosso e Mato Grosso do Sul (Eremites de Oliveira; Viana, 1999-2000). Não obstante, contextos arqueológicos caçador- 
-coletor datados em sete mil anos foram estudados na bacia do rio Vermelho, no sudeste mato-grossense (Vilhena-Vialou, 2006; Wüst, 1999), enquanto em Mato Groso do Sul são conhecidos sítios arqueológicos que podem ter sido formados por grupos caçadores-coletores, mas que ou não foram datados, a exemplo dos sítios registrados em Rio Negro (MS) (Martins, 1998), ou então que o foram apenas parcialmente, como os abrigos Maracajú-1, situado no planalto Maracajú-Campo Grande, em Maracajú (MS) (Martins, 2003), e Cera, localizado nas escarpas da serra de Maracaju-Aquidauana, em Aquidauana (MS) (Póvoa, 2007), nos quais, como se verá adiante, foram datados apenas os contextos estudados nos níveis superiores, associados à populações ceramistas.

No Pantanal sul-mato-grossense, o contexto arqueológico detectado no aterro MS-CP-22, considerado a estrutura monticular mais antiga de toda a bacia platina (Eremites de Oliveira, 2004, p.43), remete a ocupação indígena ao Holoceno Inicial (Schmitz, 1998, 1999b; Schmitz et al., 1998). Estrategicamente construído sobre um terraço fluvial na margem direita do rio Paraguai, localizado no município de Ladário (MS), entre as encostas do planalto residual do Urucum-Amolar e a planície inundável, amostras de conchas retiradas das camadas construtivas do MS-CP-22 foram datadas entre 8.100 e 8.300 anos ap. Além de vestígios líticos de lascamento e polimento, constituídos por núcleos, lascas, talhadores, percutores, bigornas, mãos de pilão, boleadeiras, lâminas de machado e adornos, também foram coletados artefatos ósseos e conchíferos, tais como pontas e contas, restos faunísticos de alimentação e sepultamentos humanos. Esse contexto arqueológico foi classificado como Fase Corumbá I.

Os responsáveis pelas pesquisas no MS-CP-22 sugerem que o aterro teria constituído algo como um assentamento central ocupado por grupos caçadores-coletores-pescadores durante cerca de duzentos anos (Schmitz et al., 1998, p.241-2). Essas populações teriam explorado recursos alimentares animais e vegetais por todo o entorno, ou seja, tanto na planície inundável, já fazendo uso da canoa, quanto nas encostas do planalto do Urucum-Amolar. Todavia, como os próprios pesquisadores admitem, o MS-CP-22 ainda é único, sendo necessário que se estudem outros contextos associados ao início da ocupação indígena no Pantanal, sejam esses mais antigos ou mais recentes que aquele, não tão somente para conhecer mais sobre os grupos do Holoceno Inicial, mas também para compreender melhor o hiato arqueológico evidenciado entre as datas obtidas no MS-CP-22 e aquelas conseguidas nos aterros construídos por grupos pescadores-caçadores-coletores aceramistas durante o Holoceno Médio, mais abundantes.

De volta ao entorno do Pantanal, foram estudados contextos arqueológicos caçadores-coletores datados do Holoceno Médio tanto no Mato Grosso como no Mato Grosso do Sul. Em Santa Elina, a indústria lítica datada entre seis e dois mil anos atrás apresenta distinções tecnotipológicas em relação às indústrias datadas do Holoceno Inicial e do Pleistoceno Final (Vilhena-Vialou, 2005, 
p.168, 173-4). Já no rio Vermelho, enquanto as pesquisas realizadas nos abrigos rupestres da Cidade de Pedras sustentam que não há alterações tecnotipológicas na indústria lítica coletada nos níveis datados entre 4.600 e dois mil anos ap (Vilhena-Vialou, 2006, p.219-21), no território Bororo foi possível distinguir uma indústria lítica datada em até cinco mil anos, detectada em abrigos sob rocha, denominada Tradição Lítica Local, de uma outra, datada em aproximadamente três mil anos ap, chamada de Tradição Tombador (Wüst, 1999, p.304). Esta última, concebida a partir de conjuntos líticos formados por grandes lascas bipolares detectadas em sítios a céu aberto, pode representar uma transição do modo de vida caçador-coletor ao agricultor, antes mesmo do estabelecimento dos primeiros grupos ceramistas portadores da Tradição Una nos abrigos da região, no início da era cristã (Wüst, 1990, 1992, 1999).

As pesquisas realizadas na margem sul-mato-grossense do alto curso do rio Paraná indicam que a trajetória histórica da ocupação indígena caçador-coletor se desenvolveu entre quatro e dois mil anos atrás, durante o último período de aridez identificado na região (Kashimoto, 1997; Kashimoto; Martins, 2000; Martins; Kashimoto; Tatumi, 1999). Embora os arqueólogos citados admitam que haja certa correlação entre as suas pesquisas e os trabalhos desenvolvidos em áreas adjacentes, sobretudo no estado de São Paulo (Morais, 1983; Pallestrini, 1984; Pallestrini; Chiara, 1978; Vilhena-Vialou, 1980), o horizonte caçador-coletor na margem direita do alto Paraná, constituído, entre outros materiais líticos talhados e retocados, por pontas de projétil, não foi inserido em nenhuma Tradição arqueológica. Contudo, é possível que se encontrem sítios líticos em Mato Grosso do Sul semelhantes aos contextos denominados de Tradição Umbu, diagnosticada principalmente pela presença de pontas de projétil líticas, e amplamente difundida nas regiões sul, onde as datas se estendem de doze mil anos ap até cerca de mil anos ap (Noelli, 1999-2000, p.231-3), e sudeste do Brasil, principalmente São Paulo, onde os contextos inseridos naquela Tradição foram datados entre seis mil anos ap e mil anos ap (Morais, 1999-2000, p.215). Os sítios a céu aberto detectados no planalto Maracajú-Campo Grande (Martins, 2003; Martins; Kashimoto, 1999a), majoritariamente constituídos por vestígios líticos lascados, mas não raro com uma ou outra ocorrência cerâmica, também podem vir a apresentar datações em torno do Holoceno Médio.

A despeito do contexto arqueológico detectado no MS-CP-22, as pesquisas arqueológicas indicam que o estabelecimento definitivo da ocupação indígena caçador-coletor-pescador no Pantanal tomou corpo no Holoceno Médio (Eremites de Oliveira, 2003, 2004; Schmitz, 1998, 1999a; Schmitz et al., 1998). Os contextos arqueológicos correlatos dessa trajetória, denominados Fase Corumbá II, foram detectados em vários aterros construídos em locais estratégicos na região de Corumbá (MS), tais como as margens das lagoas Negra e Jacadigo, e as áreas de tensão ecológica entre as terras altas e as terras baixas. Os conjuntos arqueológicos recolhidos nestes aterros são formados por materiais líticos, ósseos, 
conchíferos e restos alimentares, datados entre cinco mil e 2.500 anos atrás (Peixoto, 2003). Comparativamente, cabe destacar que os materiais líticos são ainda mais expedientes e informais que aqueles definidos na Fase Corumbá I, e que não foram encontrados sepultamentos nos cortes estratigráficos empreendidos nos aterros da Fase Corumbá II. Mesmo assim, muitos desses sítios, devido às suas dimensões e estruturas, apresentam características de assentamentos centrais, ocupados permanente e/ou sazonalmente ao longo de muitos séculos.

O estabelecimento da ocupação caçador-coletor-pescador no Pantanal coincide com o término do Optimum Climaticum, o período de estabilização das feições ambientais e geoecológicas características da biodiversidade dos distintos ecossistemas pantaneiros (Ab'Sáber, 2006; Eremites de Oliveira, 1999). Grupos indígenas distintos, originários de regiões diversas, devem ter sido atraídos pelas condições favoráveis do meio. As interações culturais entre esses grupos, por meio de relações sociais e ecológicas através do tempo, podem ter originado, em paralelo ao aumento demográfico, um sistema de ocupação peculiar, caracterizado pelo estabelecimento territorial de populações diversas em aterros construídos nas áreas mais propícias à manutenção do modo de vida caçador-coletor-pescador. Também é provável que, em conjunto à exploração dos diversos ambientes das terras baixas e altas, essas populações garantissem a sua subsistência através da realização de atividades de manejo ambiental de várias espécies vegetais, tais como a palmeira acurí e o arroz nativo do Pantanal, e até mesmo por meio de alguma agricultura incipiente (Eremites de Oliveira, 2001b).

\section{A consolidação da ocupação indígena no Pantanal}

As pesquisas arqueológicas indicam, todavia, que o Pantanal se tornou efetivamente ocupado a partir de três mil anos atrás (Eremites de Oliveira, 2003, p.79), com o desenvolvimento de processos de consolidação territorial desencadeados pelas diversas populações indígenas construtoras de aterros. A multiplicação dos aterros nas planícies inundáveis e a incorporação da tecnologia cerâmica, classificada como Tradição Pantanal, datada entre 2.800 e oitocentos anos ap, são os principais correlatos desses processos (Peixoto, 2003). Embora não se possa afirmar com todas as letras que as populações por trás da Tradição Pantanal descendam diretamente dos grupos estabelecidos na região desde o Holoceno Médio, é possível que o advento da cerâmica e o aumento do número de aterros, transformações que devem ter ocorrido em conjunto com a intensificação das atividades agrícolas e de manejo ambiental, e a complexidade sócio-histórica, sejam resultantes de processos de continuidade e mudança, desencadeados através de interações entre as populações já estabelecidas na área, em pleno crescimento demográfico, e outros grupos, recém-chegados ou então assentados em torno do Pantanal. Seja como for, ao mesmo tempo que é importante ressaltar que a Tradição Pantanal disputa com os conjuntos cerâmicos do médio curso do rio São Francisco e com a Tradição Una a posição da cerâmica mais antiga fora da Amazônia, muitos autores sugerem que a sua tecnologia 
pode ter sido reproduzida até recentemente, o que a configura como uma das tradições tecnológicas mais longevas entre as populações indígenas no Brasil (Eremites de Oliveira, 2004; Migliacio, 2000; Peixoto; Bezerra, 2004; Schmitz, 1998, 1999b; Schmitz et al., 1998).

A Tradição Pantanal foi concebida a partir das análises dos materiais cerâmicos coletados na região de Corumbá (MS) (Schmitz et al., 1998, p.22136). Em termos gerais, a Tradição Pantanal se caracteriza por vasilhas utilitárias, abertas e fechadas, como panelas, tigelas e jarras, com ou sem pescoço, contornos simples e inflectido, formas esféricas, elípticas e ovais, dimensões pequenas e médias; tratamento de superfície predominantemente alisado, com presença de tratamentos cromáticos e plásticos, por vezes sobrepostos e/ou combinados; queima a céu aberto; técnica de manufatura acordelada e uso de antiplásticos minerais. Além de fragmentos de vasilhas, não só são encontrados outros artefatos cerâmicos nos contextos arqueológicos da Tradição Pantanal, tais como cachimbos, fusos e adornos, como também artefatos ósseos, materiais conchíferos, restos alimentares e sepultamentos humanos.

Inicialmente, a variabilidade observada nos contextos arqueológicos ceramistas detectados em Corumbá (MS) conduziu à subdivisão da Tradição Pantanal em duas Fases, por sua vez denominadas Pantanal, associada aos aterros, e Jacadigo, relacionada aos piemontes do planalto do Urucum-Amolar. Ainda foi identificado um terceiro conjunto de materiais cerâmicos da Tradição Pantanal no planalto do Urucum, em Corumbá, porém por tratar-se de um achado isolado, detectado em apenas um sítio, denominado MS-CP-25, ainda não the foi atribuído uma denominação (Peixoto; Bezerra 2004; Schmitz et al., 1998).

Os contextos arqueológicos da Fase Pantanal, datados entre 2.800 e 1.700 anos, estão associados tanto aos aterros até então ocupados pelos grupos aceramistas quanto aos aterros construídos às centenas, talvez até aos milhares, pelas terras baixas da região. Aos atributos cerâmicos característicos da Tradição Pantanal soma-se, entre outros, a presença de tratamentos cromáticos como engobo vermelho, engobo branco, pintura de traços vermelhos e pretos; tratamentos plásticos funcionais, como corrugado, roletado, serrungulado, escovado e beliscado, bem como decorativos, como nodulado, acanalado, aplicado, inciso e impresso com corda; predomínio de antiplásticos minerais, mas com presença de caco moído e concha triturada; bordas extrovertidas com reforço junto ao lábio, “[...] que podem servir de diagnóstico dessa fase" (Peixoto; Bezerra, 2004). Além dos materiais cerâmicos, ainda são encontrados materiais líticos, ósseos e conchíferos, bem como restos alimentares e sepultamentos humanos primários e secundários (Figura 2).

Baseados nos dados arqueológicos resultantes do estudo dos contextos da Fase Pantanal, numa percepção um tanto determinista das pressões exercidas pelo ambiente pantaneiro e nas informações etnográficos sobre os diversos índios canoeiros outrora estabelecidos na região, tais como os Guató, Payaguá e 


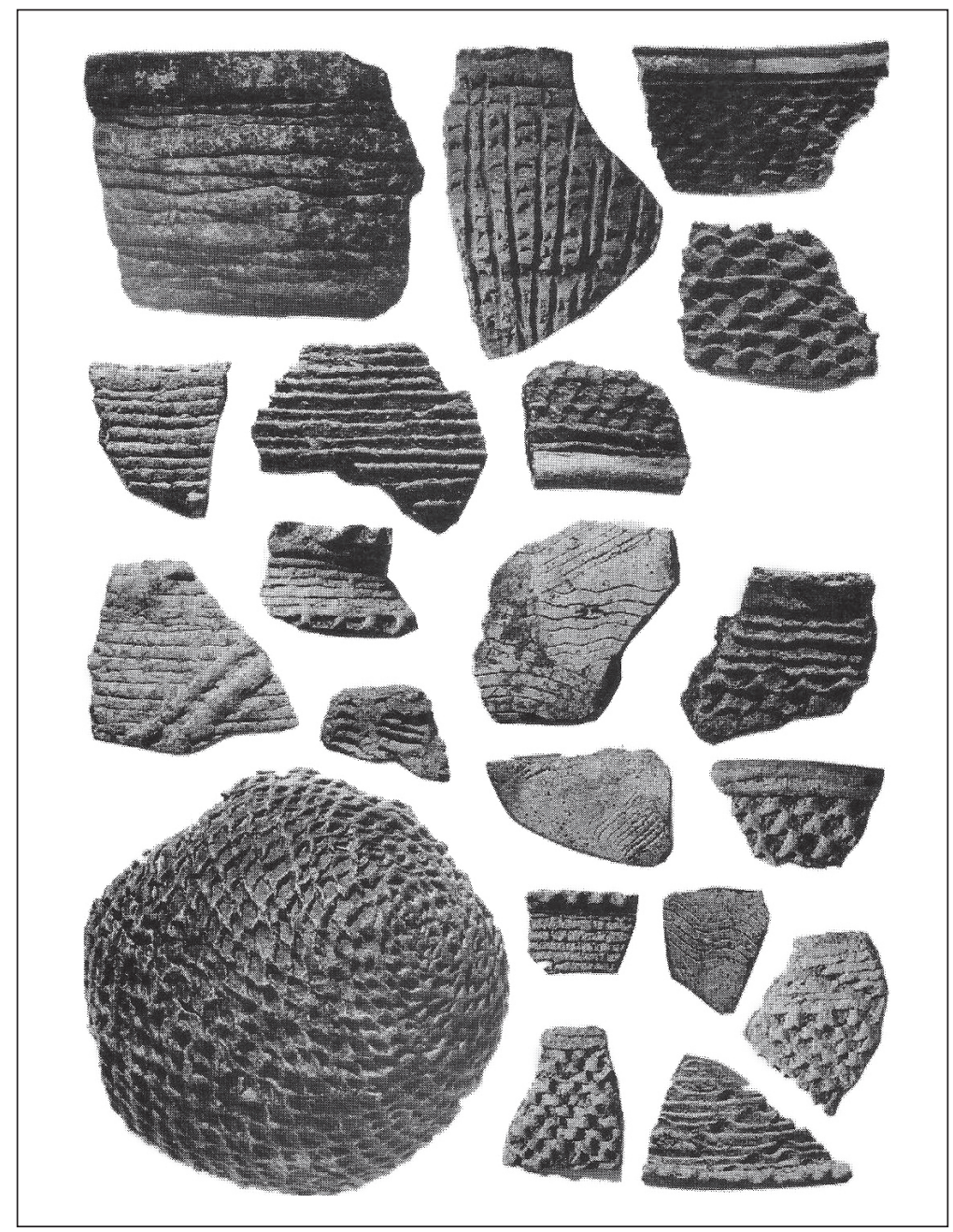

Figura 2 - "Formas de acabamento plástico da superfície da fase Pantanal" (Schmitz et al, 1998, p.257).

Guaxarapó, foi proposto um modelo inicial sobre o sistema de assentamento e a subsistência das populações ceramistas construtoras de aterros (Schmitz et al., 1998, p.240). Destarte, os aterros com dimensões avantajadas e alta densidade e variedade de materiais e estruturas, geralmente implantados nas áreas mais propícias à ocupação humana, ou seja, as margens das grandes lagoas e as áreas de tensão ecológica, foram compreendidos enquanto assentamentos centrais. Já os aterros edificados nas planícies inundáveis, por possuírem dimensões e densidades de materiais menores que aqueles, muitas vezes constituídos apenas por contextos ceramistas da Tradição Pantanal, foram entendidos como assentamentos temporários. Tendo em vista a sazonalidade do meio, marcada por uma estação seca, no inverno - quando apenas os cursos dos grandes rios e as grandes lagoas do Pantanal retêm água e outros recursos indispensáveis à sobrevivência - e outra chuvosa, no verão - momento em que as planícies permanecem 
inundadas durante alguns meses, ocasionando a dispersão dos recursos pelos pantanais e pelas áreas protegidas das cheias - os arqueólogo propuseram que os sítios centrais deveriam concentrar maior quantidade de pessoas no período seco, enquanto os aterros menores, localizados nas planícies de inundação, seriam ocupados durante as cheias. Os autores citados resumiram o modelo proposto da seguinte maneira:

O modelo resultante nos mostraria, então, assentamentos centrais, mais densos e permanentes, para os quais a população dispersa se recolheria no tempo da vazante e assentamentos periféricos e temporários, de populações dispersas durante o tempo da enchente. Apesar da necessidade de parte da população ter de dispersar durante a enchente, provavelmente os assentamentos centrais manteriam populações residentes $o$ ano inteiro, guardando o espaço dos vivos e dos falecidos. (Schmitz et al., 1998, p.240)

Não obstante, Eremites de Oliveira (2003, p.80-1, 2004, p.76-9), estimulado pelo modelo utilizado para entender a emergência da complexidade social entre populações construtoras de sambaquis no Brasil e de cerritos no Uruguai, tem argumentado que os contextos arqueológicos constituídos pelos aterros devem ser entendidos como algo muito mais complexo que apenas como respostas adaptativas às condições impostas pelo meio físico e ambiental no Pantanal. $\mathrm{O}$ autor citado advoga que a construção dos aterros " [...] requereu o uso de conhecimentos arquitetônicos e a organização do trabalho social, além de fatores ideológicos, relações de poder e estratégias de territorialidade, ou seja, estratégias de domínio da paisagem natural e social dentro de uma visão cognitiva do universo" (Eremites de Oliveira, 2003, p.80).

Já os contextos arqueológicos classificados na Fase Jacadigo foram coletados em sítios a céu aberto, implantados nas encostas suaves dos piemontes do planalto residual do Urucum-Amolar (Schmitz et al., 1998, p.226-8). As variações nas dimensões e nos conteúdos dos contextos dos sítios da Fase Jacadigo também sugerem a existência de assentamentos centrais e acampamentos sazonais. Ao mesmo tempo que os materiais cerâmicos da Fase Jacadigo se inserem na Tradição Pantanal pela presença dos seus atributos característicos, diferem da Fase homônima não só pelo padrão de implantação dos sítios, mas também por variações na forma das vasilhas, com ocorrência de fragmentos carenados, denotando contornos complexos - aos quais foi atribuída certa influência de populações de língua Tupi-Guarani; no tratamento de superfície cromático, com predomínio de engobo vermelho, e plástico, tanto em termos funcionais - com corrugado, roletado, beliscado e serrungulado - quanto decorativos - com impressão de corda, inciso, ungulado, aplicado e nodulado; na presença de apêndices de suspensão, sobretudo alças; e, entre outros atributos, na ausência de caco moído e concha triturada como antiplástico (Peixoto; Bezerra, 2004). Além dos materiais cerâmicos característicos da Tradição Pantanal, como cachimbos, fusos 
e adornos, os contextos da Fase Jacadigo também são constituídos por restos faunísticos de alimentação, os quais, por sua vez, também são distintos daqueles estudados nos aterros, haja vista que não são encontrados remanescentes de peixes e moluscos, apenas de mamíferos, répteis e aves.

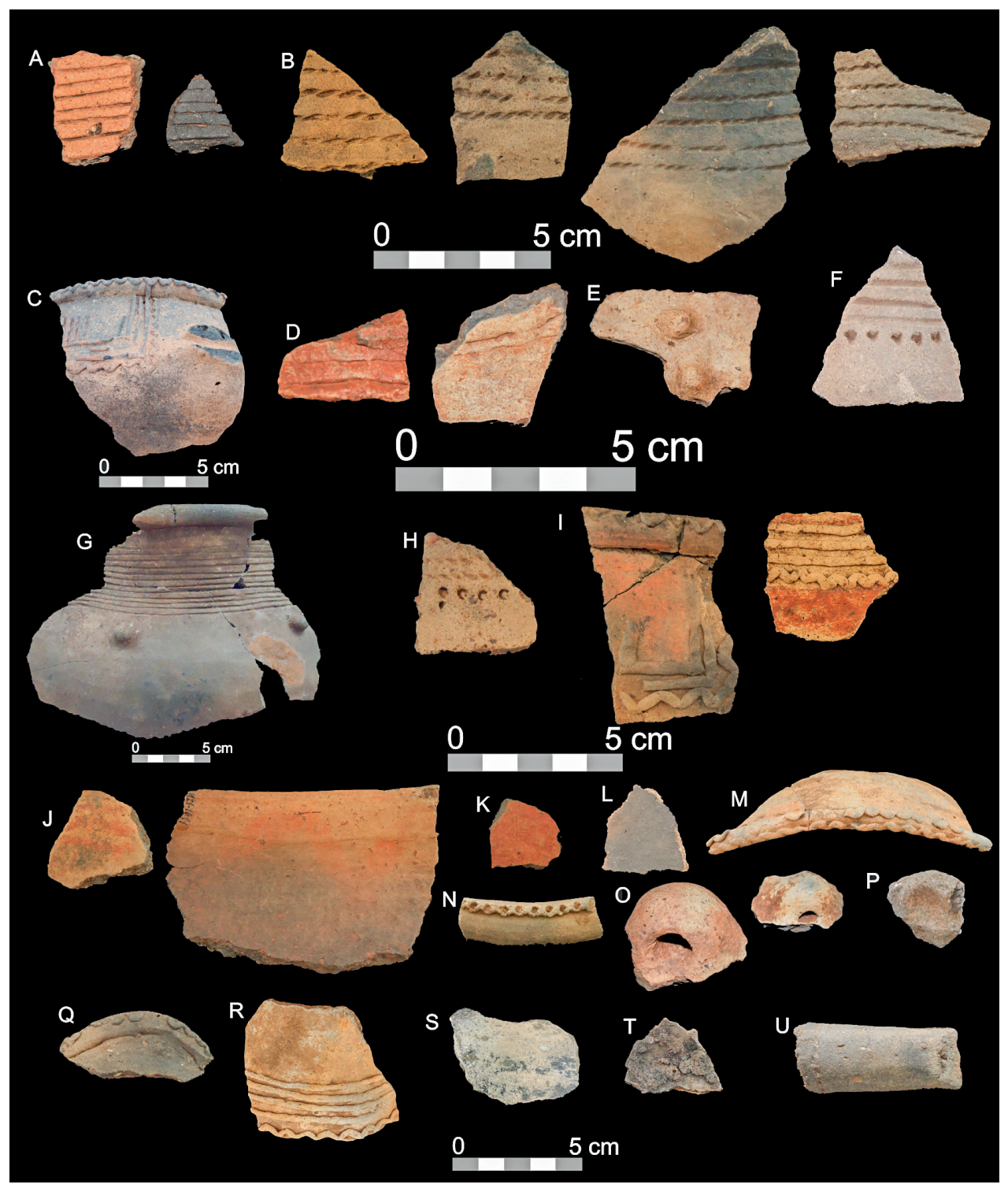

Figura 3 - Materiais cerâmicos da Fase Jacadigo na Terra Indígena Lalima: A) inciso; B) impressão de corda; C, M, Q-R) apliques de filigranas de argila; D) corrugado-simples; E) aplique mamilonar; F) inciso-ponteado; G) inciso-aplicado (com aplique mamilonar); $\mathrm{H}$ ) impressão de corda-ponteado; I) aplique de filigranas e pintura vermelha; J) pintura vermelha; $\mathrm{K})$ engobo vermelho; L) enegrecimento; N) ponteado; O) apêndice de suspensão (alça); P) apêndice de suspensão (asa); S) fuligem; T) depósito de carbono; U) cachimbo troncular (Bespalez, 2014, p.184). 
Os sítios da Fase Jacadigo não foram datados, mesmo assim os pesquisadores que a conceberam suspeitaram que "[...] sejam recentes, talvez taperas dos pastores Mbayá-Guaicuru do séc. XIX" (Schmitz et al., 1998, p.228). No entanto, datações de contextos arqueológicos associados a conjuntos de materiais cerâmicos análogos aos da Fase Jacadigo, detectados nos abrigos Cera, na serra de Maracaju, em Aquidauana (MS) (Póvoa, 2007, p.40), no sítio Campina 1, implantado em uma caverna na serra da Bodoquena, em Bodoquena (MS) (Martins; Kashimoto; Tatumi, 1999, p.91), e na Terra Indígena Lalima, na margem direita do alto curso do rio Miranda, em Miranda (MS) (Bespalez, 2009, p.83, 2010, p.118, 2014, p.165), situadas entre 1.070 e 550 anos ap, sugerem que os portadores de tecnologias ceramistas similares à Fase Jacadigo podem ter se estabelecido em torno das planícies inundáveis do Pantanal antes da chegada dos europeus e se mantido na região até o período colonial. Há ainda um sítio com alguns fragmentos cerâmicos detectados no cór. Varadouro, um afluente do Aquidauana, no município de Terenos (MS), próximo a Campo Grande, datado em 1.135 anos ap (Martins; Kashimoto, 1999a, p. 25).

Seja como for, não só é provável que os portadores da Fase Jacadigo possam ser compreendidos mais como agricultores do que como pastores, como ainda é possível que estejam relacionados com a trajetória histórica e cultural de povos como os "Jerabayenes", aludidos por Rui Diaz de Guzman em "Argentina", escrita em 1.612, e com os "Gualachos Labradores", descritos pelo Pe. Ferrer na ânua remetida das Missões do Itatim em 1.633. De acordo com Guzman (1882, p.36), os Jerabayenes, assim denominados por ocuparem as proximidades da cidade espanhola de Santiago de Xerez, transladada para as margens do rio Aquiduauana, então denominado "Botetey", no ano 1600, seriam aparentados dos "Jarayes", estabelecidos no alto curso do rio Paraguai, e dos "Maneses", assentados em torno de Santa Cruz de La Sierra, na Bolívia, já que "todos se apellidan Jarayes". Provavelmente, os processos históricos e culturais dos Jarayes, mais grafados atualmente como Xaray, e dos Maneses, os quais correspondem aos Chané, podem estar correlatos, respectivamente, nos materiais arqueológicos das tradições Descalvados, encontrada no alto Paraguai, e Estampada e Incisa de Bordas Dobradas, nos vales interandinos e no Chaco boliviano (Migliacio, 2000, 2000-2001, 2006; Alconini Mcelhinny; Rivera Casanovas, 2003).

O Pe. Ferrer, por sua vez, dividiu os povos indígenas na região do Itatim, um antigo território do Paraguai colonial situado entre a Serra de Maracajú, no interflúvio Paraná-Paraguai, ao leste, o rio Paraguai, a oeste, a cidade de Assunção, ao sul, e o rio "Buteteỹ", ao norte, em dois grandes grupos: os Guarani, também referidos como Itatim, e os Gualacho. Os últimos, conforme esclarecido pelo próprio Pe. Ferrer (Cortesão, 1952, p.45-8), "comprehendense todas las naciones que no tienen por propria la lengua Guarani", tais como os "Guana", "Tunus", "Bayas", "Guaramos", "Guaycurus" ou "Guaycurutis", "Guayarapos", "Payaguas", "Charayes" e "Orejones", estabelecidos, majoritariamente, 
sobre o rio Paraguai ou na sua margem direita. Todavia, ainda segundo o Pe. Ferrer (Cortesão, 1952, p.29), o "rio Buteteỹ", localizado na margem esquerda do Paraguai, "esta cuajado de muchissimos Gualachos labradores", os quais, por sua vez,

[...] tienen pueblos fixos e chacaras grandes y en ellas todo lo que tienen los Guaranis, y no difieren en nada dellos sino en la lengua, aunque diz que tambien ellos... tienen una lengua o dos universales, y entran a contratar con estos Itatines. tengo escrito dellos mas de veinte pueblos. tienen buen natural $y$ algunos dizen que es aun mejor que el de los Guaranis. tienen mucho arroz que recogem por sus lagunas, y son grandes pescadores [...] el mejor pescador es el mas estimado: ninguno come de su caça o pesca sino de la de su vezino, y el reparte toda la suya entre sus vezinos, cada uno tiene um nombre de diferente pescado, y por ningun caso a de comer el pescado de su nombre [...] no tocan a la comida con la mano sino con pinças de palo, y el caldo lo chupam com mazorcas de maiz [...]. (Cortesão, 1952, p.47-8)

Apesar de detectados nas terras altas do Planalto do Urucum-Amolar, assim como os contextos da Fase Jacadigo, os materiais cerâmicos do MS-CP-25, por sua vez, variam em relação àqueles e aos da Fase Pantanal principalmente em termos decorativos, haja vista que predominam padrões geometrizados feitos com impressões de corda e policromia. Também devem-se destacar as ocorrências de bordas com entalhes e incisões labiais, bem como a presença de antiplásticos compostos por conchas trituradas. O MS-CP-25 também não foi datado, porém, do mesmo modo como no caso da Fase Jacadigo, Schmitz et al. (1998, p.229) sublinharam que “[...] A muita Impressão de Corda faz lembrar novamente a cerâmica dos Mbayá-Guaicuru, atualmente chamados Kadiwéu [...]”.

Em Porto Murtinho (MS), um contexto arqueológico implantado sobre um dique aluvial da margem esquerda do rio Paraguai, no sítio Cayman I, também apresenta materiais cerâmicos “[...] cujas características lembram a cerâmica dos Kadiwéu, o que obviamente não significa que foram eles que as produziram" (Eremites de Oliveira, 2004, p.94). Na Terra Indígena Lalima também foram detectados fragmentos cerâmicos análogos aos do sítio MS-CP-25 (Figura 4), os quais, por sua vez, foram compreendidos como correlatos da migração e do estabelecimento dos Guaikuru e Guaná na região de Miranda (Bespalez, 2014).

Posteriormente, pesquisas realizadas no Pantanal de Cáceres (MS) (Migliacio, 2000, 2006) e na lagoa do Castelo, em Corumbá (MS) (Peixoto, 2003), conceberam outras duas Fases cerâmicas da Tradição Pantanal associadas aos aterros, respectivamente denominadas Taiamã e Castelo. A primeira, datada entre 1.200 e mil anos ap, varia em relação às outras sobretudo pela preponderância de decorações plásticas realizadas com impressões de corda, porém essas não chegam a constituir motivos geométricos como no contexto do MS-CP-25. A Fase Taiamã também se destaca pela presença de caco moído, concha triturada e cauixi enquanto antiplásticos. No pantanal de Cáceres também foi observado outro contexto cerâmico, denominado Inciso-Penteado (Migliacio, 2000). 
Já a Fase Castelo, datada entre 2.600 e 1.300 anos ap, também apresenta variações em relação às demais Fases da Tradição Pantanal. Considerando o tratamento de superfície, predominam decorações plásticas efetuadas por incisões e cromáticas realizadas com banhos de engobo branco e vermelho. Também ocorrem antiplásticos constituídos por conchas trituradas e cauixi, porém não foi observado caco moído (Peixoto, 2003; Felicíssimo et al., 2004).

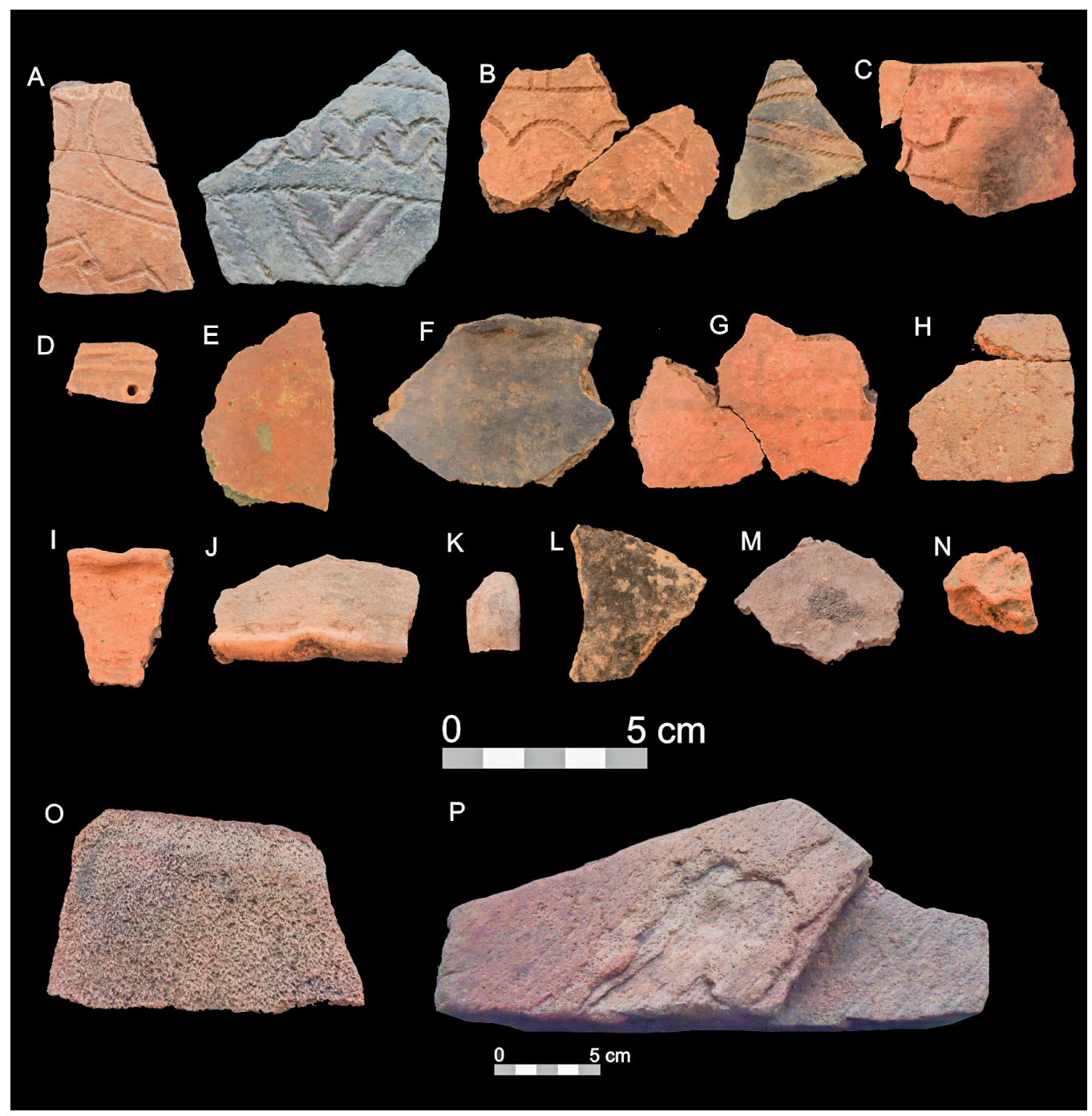

Figura 4 - Materiais arqueológicos Guaikuru na Terra Indígena Lalima: cerâmicos: A) impressão de corda; B) impressão de corda e policromia; C) inciso e engobo vermelho; D) perfurado; E) engobo vermelho; F) enegrecimento; G) pintura preta sobre engobo vermelho; H) barbotina; I-J) lábio modelado; K) apêndice de suspensão (alça); L) fuligem; M) depósito de carbono; N) bolota de argila; líticos: $\mathrm{O}$ ) afiador; $\mathrm{P}$ ) quebra-coco (Bespalez, 2014, p.203). 
Outros aterros ocupados por populações ceramistas no Pantanal foram registrados nas sub-regiões do Paraguai, São Lourenço e Poconé, no Mato Grosso (Eremites de Oliveira, 2007; Schmidt, 1940a, 1940b), e nos Pantanais do Nabileque, na região do município de Porto Murtinho (MS) (Boggiani, 1900; Eremites de Oliveira, 2004). Na região de Poconé, um sítio a céu aberto localizado nas proximidades do Morro do Cará-cará, em uma área então ocupada por dois índios Guató, foi datado em oitocentos anos ap (Eremites de Oliveira; Viana, 1999-2000, p.171). Além do mais, Eremites de Oliveira (2004, p.45) considera que contextos arqueológicos semelhantes àqueles que constituem a Tradição Pantanal no Brasil foram estudados no Chaco paraguaio, boliviano e argentino, onde foram respectivamente classificados como Wettiadau-Mbayá (Susnik, 1959), Guaná-Mbayá (Susnik, 1984), Complexo Cultural Alto-Paraguaiense (Gómes-Perasso, 1978), Tradição Chaquenha (Willey, 1971), Cultura São Francisco (Ortiz, 2003, 2013) e Tradição Ribeirinha Paranaense (Amílcar-Rodrigues, 1992), mais referida atualmente como Entidade Goya-Malabrigo (Ceruti, 2003; Ceruti; González, 2007; Politis; Bonomo, 2012).

Também são conhecidos vários sítios com arte rupestre no Pantanal. Denominados Estilo Alto Paraguai, os contextos arqueológicos com arte rupestre são constituídos tanto por petróglifos, como aqueles pesquisados nos lajedos da região de Corumbá (MS) e nos morros testemunhos próximos à lagoa Gaíva, quanto por pictoglifos, a exemplo das pinturas detectadas na região de Porto Murtinho (MS) e no morro do Cará-cará (Girelli, 1994; Schmidt, 1940b; Eremites de Oliveira, 2004, 2007). Mesmo considerando que esses sítios ainda não foram relacionados aos distintos contextos arqueológicos identificados na região, há certa tendência em correlacioná-los aos "[...] antigos grupos que construíram e/ou ocuparam aterros" (Eremites de Oliveira, 2004, p.59). Como aludido acima, também existem dezenas de sitos com arte rupestre nos planaltos circum-adjacentes ao Pantanal, muitos deles em abrigos sob rocha, tanto em Mato Grosso e Mato Grosso do Sul quanto na Bolívia (Kaifler, 1999, 2002, 2006; Martins, 1998, 2002a, 2003; Martins; Kashimoto, 2012; Póvoa, 2007; Riester, 1981; Schmitz, 1998; Vilhena-Vialou, 2005, 2006; Wüst 1999).

\section{A Tradição Pantanal e os povos Mbayá-Guaikuru}

Como frisado por Schmitz et al. (1998, p.12), as Fases Corumbá I e II, a Tradição Pantanal e o Estilo Alto Paraguai foram concebidos no ínterim de um projeto cujos objetivos consistiam em "[...] criar uma história contínua das populações indígenas, abrangendo o período pré-histórico e o colonial, com eventuais transgressões para o período nacional". Posteriormente, diante da descoberta da enorme variação nos conjuntos cerâmicos dos contextos arqueológicos no Pantanal, pesquisadores como Eremites de Oliveira $(2004$, p.79) passaram a entender a Tradição Pantanal como uma macrotecnologia, constituída "[...] de elementos cerâmicos relacionados a distintos estilos e etnicidades". Ao mesmo tempo, os arqueólogos passaram a admitir que a tecnologia da Tradição Panta- 
nal pode ter sido reproduzida entre as populações indígenas até recentemente, e existe "[...] possibilidades de pertencerem a grupos étnicos coloniais", como sugerido, entre outros, por Peixoto e Bezerra (2004).

Apesar da presença de muitas populações falantes de línguas isoladas ou então inseridas em famílias linguísticas menores, como os Chamacoco e os Yshir, cujas línguas foram agrupadas na família Zamuco, a maioria das populações indígenas que ocupavam o Chaco no século XVI falavam línguas do tronco Mbayá-Guaikuru (Carvalho, 1992; Eremites de Oliveira, 2004; Herberts, 1998; Métraux, 1946; Susnik, 1971; Urban, 1992). Antes da conquista, segundo Métraux (1946, p.214), os Mbayá-Guaikuru estavam estabelecidos entre o rio Paraguai e os rios Pilcomayo e Bermejo, ambos afluentes daquele pela margem direita. Contudo, é provável que já houvesse populações Mbayá-Guaikuru estabelecidas a jusante, no rio Paraná, e a montante, nos pantanais do Abobral e do Miranda-Aquidauana, a exemplo dos Guaxarapó ou Guachi (Cabeza de Vaca, 1985; Castelnau, 1949; Lozano 1754-1755, Rondon, 1949; Schmidel, 1986; Taunay, 1868).

Os principais grupos Mbayá-Guaikuru eram constituídos pelos Abipon, Mocovi, Toba, Pilagá, Payaguá e Mbayá. Os Payaguá eram grupos canoeiros que ocupavam o rio Paraguai, tanto no território atual do país homônimo quanto na fronteira do Brasil com a Bolívia, no Pantanal (Taunay, 1981; Schmidt, 1949). O próprio termo Paraguai, inclusive, deriva de uma corruptela de origem espanhola da expressão Guarani Payaguá'y, que significa "rio do Payaguá", sendo Payaguá um dos caciques dos Evuevi, a autodenominação étnica proferida pelos Payaguá. Os Mbayá ou Guaikuru - termo de origem Guarani, que quer dizer "gente malvada e suja", usado por aqueles para expressar alteridade em relação aos grupos chaquenhos de modo geral - ocupavam a área em torno do delta do Pilcomayo, defronte Assunção, e se autodefiniam como Eyguayegui, que significa "habitantes dos palmeirais" (Sanchez Labrador, 1910). Os Mbayá, a exemplo dos Kadiwéu, Cotoguéo e Beuaquéu, incorporaram o cavalo no seu ethos móvel e aguerrido, e se expandiram para o norte, se estabelecendo no Pantanal, em áreas então ocupadas pelos Guarani ou ainda por outras populações, enquanto os demais Mbayá-Guaikuru se espalharam pelo Chaco, sobretudo nas direções sul, sudoeste e oeste de Assunção (Almeida Serra, 1845; Bastos, 1972; Costa, 1999; Ferreira, 1971; Hemming, 2007; Rodrigues do Prado, 2009; Weber, 2002).

Hipóteses arqueológicas e linguísticas sobre as origens dessas populações ainda não foram propostas sistematicamente, embora seja pleiteada uma provável origem pampiana antiga e uma certa relação com os contextos arqueológicos da Tradição Pantanal. Com efeito, é inegável que a cerâmica dos Kadiwéu, reproduzida nos moldes atuais ao menos desde a viagem filosófica de Alexandre Rodrigues Ferreira, no final do século XVIII, apresenta alguns traços em comum com aquelas detectadas nos contextos arqueológicos da região. Apesar da tecnologia cerâmica Kadiwéu ainda não ter sido abordada através de uma pers- 
pectiva etnoarqueológica, descrições decorrentes de observações diretas podem ser vistas em Sanchez Labrador (1910), Rivasseu (1936), Lévi-Strauss (1986), Ribeiro (1980, p.287-95) e Siqueira Jr. (1992). As semelhanças entre esses traços foram observadas em maior profusão nos contextos da Fase Jacadigo e do sítio MS-CP-25, em Corumbá (MS) (Schmitz et al, 1998), no sítio Cayman I, em Porto Murtinho (MS) (Eremites de Oliveira, 2004) e na Terra Indígena Lalima (Bespalez, 2014), áreas historicamente ocupadas por diversos grupos Mbayá desde o período colonial. Contudo, também se observam alguns elementos comuns entre as cerâmicas suspeitas como mais recentes, achadas nas terras altas do Pantanal, e aquelas definidas nas Fases mais antigas da Tradição Pantanal, coletadas nos aterros.

Com isso, é importante sublinhar, não se está sugerindo uma relação essencialista entre a Tradição Pantanal e as populações de matriz cultural Mbayá-Guaikuru, mesmo levando em conta que essas eram as mais populosas do Chaco e admitindo que elas possuíam certos mecanismos sociais, tais como a alta mobilidade, guerra de rapina e circulação de cativos, que poderiam criar um ambiente propício ao desencadeamento de processos de mudança cultural, como o advento da cerâmica e da agricultura. Tudo leva a crer que a Tradição Pantanal está associada à populações indígenas diversas, originadas com o desenvolvimento cultural dos caçadores-coletores-pescadores do Holoceno Médio e com as interações desses com os povos que foram se estabelecendo na região posteriormente. Nesse sentido, o que se especula aqui é que populações de matriz cultural Mbayá-Guaikurú podem ter se consolidado no Chaco desde antes da formação do mosaico cultural encontrado pelos europeus no século XVI.

\section{A formação do mosaico cultural encontrado pelos europeus e os impactos do colonialismo}

Provavelmente, a configuração etnográfica encontrada pelos europeus foi constituída entre o início da era cristã e o milênio subsequente, quando populações portadoras de matriz cultural Macro-Jê, de um lado, e Guarani e Aruak, de outro, se expandiram do Brasil Central e da Amazônia, e se estabeleceram no Pantanal (Brochado, 1984; Eremites de Oliveira, 2003; Heckenberger, 2002; Noelli, 1996; Wüst, 1992). As trajetórias dessas populações foram distintas em termos cronológicos, espaciais e culturais, porém, de um modo ou de outro, todas foram impactadas pelo colonialismo.

\section{Os povos Macro-Jê}

As populações portadoras de matriz cultural Macro-Jê, originada no Brasil Central, talvez tenham contribuído com a formação do mosaico cultural registrado a partir do período colonial desde antes da chegada dos Tupi e dos Aruak. Os dados históricos e etnográficos apontam que povos Marco-Jê ocuparam as porções nordeste, oeste e sudeste do entorno do Pantanal, nas áreas sob influência dos cerrados localizadas nos patamares do Planalto Central e nos piemontes entre aqueles e as planícies inundáveis, território tradicional dos índios Bororo, 
Umutina, Kayapó do Sul e, talvez, dos Ofayé-Xavante, e os pantanais do Poconé e do Paraguai, regiões tradicionalmente ocupadas pelos Guató (Eremites de Oliveira, 1996; Prezia, 2000; Urban, 1992; Wüst, 1992).

No rio Vermelho, no território dos Bororo, as Tradições Una e Uru, em geral associadas às populações Macro-Jê, foram respectivamente datadas em 2.390 e 1.150 anos ap (Wüst, 1999, p.305). Na Cidade de Pedras, as ocupações ceramistas foram datadas entre 1.900 e 250 anos ap (Vilhena-Vialou, 2006). A Tradição Una, datada em até três mil anos ap na região sudeste e caracterizada por vasilhame cerâmico simples, utilitário e de pequenas proporções, geralmente é detectada em abrigos sob rocha, podendo estar relacionada com populações caçadoras-coletoras tardias, em transição para a agricultura, ou então com áreas de atividades específicas das populações portadoras da Tradição Aratu-Sapucaí (Dias Júnior; Carvalho, 1982; Henriques; Costa; Koole, 2004). Já a Tradição Uru, constituída por vasilhame bastante diversificado, relacionada ao tratamento da mandioca amarga, geralmente é encontrada em sítios a céu aberto associados às grandes aldeias circulares na região centro-oeste do Brasil, as quais podiam ser ocupadas por várias centenas e até mesmo por algumas milhares de pessoas (Eremites de Oliveira; Viana, 1999-2000; Robrahn-González, 1996; Wüst, 1992).

Na região centro-sul do Brasil, os contextos arqueológicos associados às populações Jê do sul, classificados como Tradição Taquara, Itararé e Casa de Pedra, foram datados em aproximadamente dois mil anos atrás (Noelli, 19992000, p.244-5). Com a extinção dos Otti-Xavante na primeira metade do século $\mathrm{XX}$, os Kaingang, confinados em reservas indígenas em São Paulo e nos estados da região sul, e os Xokleng, presentes apenas em Santa Catarina, são os últimos remanescentes dessas populações no sul-sudeste.

Até o início do século XX, os planaltos adjacentes ao Pantanal ainda eram ocupados pelos Kayapó meridionais, populações Jê amplamente distribuídas entre São Paulo, Minas Gerais, Goiás, Mato Grosso e Mato Grosso do Sul - uma região até hoje referida como Kayapônia. Os Kayapó do sul podem estar relacionados às populações portadoras da Tradição Aratu, caracterizada por vasilhame cerâmico diversificado, mais adequado ao tratamento do milho, datada no centro-oeste em até 1.100 anos ap (Eremites de Oliveira; Viana, 1999-2000; Robrahn-González, 1996).

Os últimos remanescentes Jê em Mato Grosso do Sul são os Ofayé-Xavante, os quais atualmente ocupam uma área doada pela Cesp na margem esquerda do alto Paraná (Martins, 2002a). Sabe-se que um grupo Ofayé ocupou a região do rio Taboco, um afluente da margem direita do alto Aquidauana, após a Guerra do Paraguai. Depois de sofrerem violências dos fazendeiros, esses Ofayé se dispersaram em direção aos pantanais do rio Negro, onde desapareceram (Rondon, 1949). É provável que os ancestrais dos Ofayé ocupassem o planalto de Maracajú-Campo Grande, nas regiões entre os territórios dos Kayapó Meridionais e dos Guarani. 


\section{Os Tupi}

A arqueologia considera que os falantes de línguas da família Tupi-Guarani, do Tronco Tupi, sobretudo Guarani - encontrados pelos europeus no litoral da região centro-sul do Brasil e na bacia platina, inclusive Argentina, Paraguai e Bolívia - foram os primeiros dentre os povos de origem amazônica a se consolidar na região. Em Foz do Iguaçu, no estado do Paraná, foi obtida uma data em torno de dois mil anos atrás (Chmyz, 1982, 1983). Outras datações antigas, entre 1.800 e 1.600 anos ap, foram alcançadas nos vales dos rios Jacuí e Uruguai, no Rio Grande do Sul (Schmitz; Brochado, 1972), na bacia do Paranapanema, em São Paulo e no Paraná (Brochado, 1973; Faccio, 1998), e nos piemontes das serras andinas orientais, na Bolívia (Pärssinen, 2005). Datas entre $1.400 \mathrm{e}$ 1.200 anos são abundantes por toda a bacia platina, enquanto aquelas em torno de oitocentos estão presentes na maioria das áreas historicamente ocupada pelos Guarani no início da colonialismo (Bonomo et al., 2014; Laponte; Acosta, 2008; Martins; Kashimoto; Tatumi, 1999; Milheira, 2008; Noelli, 1999-2000; Mentz Ribeiro, 2008; Soares, 2004).

Em Mato Grosso do Sul, a ocupação Guarani foi datada entre 1.300 e 300 anos ap na margem esquerda do rio Paraná, no segmento entre as desembocaduras dos rios Amambaí e Invinhema, localizado defronte à foz do Paranapanema, e entre oitocentos e seiscentos anos ap no abrigo Maracajú-1, situado nos formadores da bacia do Ivinhema (Chmyz, 1974; Kashimoto; Martins, 2008; Martins, 2003; Martins; Kashimoto; Tatumi, 1999). O contexto arqueológico Guarani pesquisado por Chmyz (1974) na margem sul-mato-grossense do alto Paraná foi denominado Fase Ivinhema. No Pantanal, um sítio Guarani foi datado em quinhentos anos ap na reserva dos índios Kadiwéu e outros tantos foram detectados no planalto do Urucum-Amolar, em Corumbá (MS), mas ainda não foram datados (Kashimoto; Martins, 2008; Peixoto, 1998). Na Terra Indígena Lalima, os correlatos da ocupação Guarani foram datados em 960 anos ap (Bespalez, 2009).

De volta à margem esquerda do rio Paraná, porém agora no segmento situado entre as confluências dos rios Pardo e Verde, em frente à desembocadura do Tietê - ou seja, ao norte do segmento entre os rios Amambaí e Ivinhema - foram detectados conjuntos cerâmicos classificados como "Tupiguarani não-Guarani” (Kashimoto; Martins, 2008, p.165), devido à baixa densidade de materiais em relação aos contextos classificados como Guarani, localizados mais ao sul, às variações no tratamento de superfície e às formas subarredondadas e subquadrangulares, semelhantes àquelas descritas por Brochado (1984) como pertencentes à Subtradição Tupinambá. Na mesma área, entendida como próxima da fronteira entre os Guarani e os Tupinambá, também foram coletados vestígios cerâmicos datados entre 2.200 e seiscentos anos ap, os quais, por sua vez, podem estar relacionados com ocupações distintas e ainda mais antigas que as Tupi. 
No entorno do Pantanal, foram detectados outros conjuntos Tupi não classificados como Guarani no rio Vermelho, em Mato Grosso. Nos abrigos sob rocha da Cidade de Pedras, as cerâmicas descritas como "[...] fragmentos que trazem traços estilísticos característicos da Tradição Tupi-Guarani” (Berra; DeBlasis, 2006, p.199) foram coletadas nas camadas estratigráficas mais recentes, enquanto os sítios a céu aberto, sendo um deles datado entre 650 e trezentos anos ap, foram ocupados por populações ceramistas portadoras das Tradições Uru e Tupi (Figuti, 2006, p.214). Já no território Bororo, a cerâmica da "Tradição Tupiguarani Polícroma" (Wüst, 1999, p.305), foi datada em 680 anos ap. A propósito, as pesquisas efetuadas junto aos Bororo indicam que esses, cuja cerâmica foi datada em 230 anos ap, podem ter uma origem relativamente recente, resultante da fusão cultural entre os Tupi e as populações portadoras das Tradições Una e Uru (Wüst, 1990, 1992, 1999).

Não obstante, considerando que os dados linguísticos apontam que o provável centro de origem do tronco Tupi situa-se onde atualmente se encontra o estado de Rondônia, "[...] na área próxima da bacia do Madeira-Guaporé” (Noelli, 1996, p.31; Rodrigues, 1964, p.103), e que a expansão dessas populações teria se desencadeado de norte a sul - inicialmente pelos grandes cursos fluviais, como o rio Paraguai, alcançado a partir do alto Guaporé, e, posteriormente, pelos afluentes de menor porte, e assim sucessivamente -, é possível que se encontrem datas tão antigas em Mato Grosso e Mato Grosso do Sul quanto aquelas obtidas nas regiões adjacentes. Por outro lado, embora haja certo consenso quanto ao provável centro de origem, uma vez que a sua localização definitiva ainda não foi estabelecida arqueologicamente, também é importante frisar que a revisão dos dados disponíveis e o surgimento de novas descobertas, como aquelas efetuadas na Bolívia (Pärssinen, 2005), podem sugerir outras rotas de expansão (Almeida, 2008; Cruz, 2008; Heckenberger; Neves; Petersen, 1998; Urban, 1992; Viveiros de Castro, 1996).

Os contextos arqueológicos Guarani são constituídos por sítios diversos, nunca isolados, desde aqueles com grandes dimensões, não raro ocupados por vários séculos a fio - por vezes até por mais de um milênio -, até aqueles de pequenas dimensões, limitados a uma ou outra ocorrência cerâmica ou lítica (Noelli, 1993, 2004). Os sítios podem estar implantados tanto nos terraços fluviais nas margens dos rios de primeira e segunda ordem quanto nos topos e encostas das colinas suaves dos tributários de menor porte. Os materiais arqueológicos são formados principalmente por fragmentos de vasilhas cerâmicas, vestígios líticos de lascamento e polimento, núcleos de solos antropogênicos, tembetás e enterramentos em urnas funerárias. Não só os sítios podem estar implantados sobre contextos arqueológicos distintos, pertencentes a outras tradições tecnológicas, como são encontrados materiais tecnologicamente diferenciados nos contextos arqueológicos Guarani e materiais Guarani em outros contextos arqueológicos. 
Apesar das variações, as vasilhas cerâmicas apresentam características estilísticas típicas e peculiares, reproduzidas continuamente desde o início da ocupação Guarani até o colapso causado pelo colonialismo (La Salvia; Brochado, 1989; Kashimoto; Martins, 2008; Mentz Ribeiro, 2008; Noelli, 1999-2000). As formas diversas, constituídas por vasilhas abertas e fechadas, com contornos simples, inflectidos, compostos e complexos, formatos conoidais e arredondados, bem como dimensões pequenas, médias e grandes, denotam utilidades várias, associadas ao processamento, consumo e armazenamento de alimentos diversos, sejam sólidos ou líquidos. Apesar de as formas serem mais adequadas ao tratamento do milho, também são conhecidos fragmentos pertencentes a vasilhas propícias ao tratamento da mandioca nos contextos Guarani, como os tostadores utilizados na fabricação de farinha e beiju (Brochado; Monticelli, 1994). Os antiplásticos eram constituídos principalmente por minerais e cacos moídos, o acordelado era a técnica de manufatura predominante e a queima era a céu aberto (Figura 5).

Se bem que o alisamento ainda predomine nas faces das vasilhas cerâmicas, tratamentos de superfície cromáticos e plásticos geralmente estão presentes em densidades consideráveis (La Salvia; Brochado, 1989). A respeito dos tratamentos cromáticos, destacam-se as pinturas de linhas e/ou faixas vermelhas e/ou pretas sobre engobo branco, muitas vezes compondo motivos ricamente elaborados, tanto na face externa quanto na interna. Entre os tratamentos plásticos funcionais, predominam as inúmeras variedades de corrugados, com presença de roletados, escovados, espatulados, beliscados e serrungulados, enquanto entre os plásticos decorativos sobressaem-se os ungulados e os incisos, entre muitos outros, combinados ou sobrepostos.

Não raro, são encontradas vasilhas inteiras intactas e/ou fragmentadas nos contextos arqueológicos, sobretudo nas estruturas de sepultamento em urnas funerárias, nas quais não só determinadas vasilhas eram utilizadas como recipientes e tampas dos restos mortais, como também integravam a parafernália que acompanhava o morto na sepultura (Piedade; Soares, 2000). Ainda podem ser encontrados artefatos cerâmicos modelados nos contextos arqueológicos Guarani, tais como cachimbos e adornos.

Com o objetivo de estudar a relação da cerâmica Guarani com os outros aspectos da cultura, mas principalmente em relação à adaptabilidade e à subsistência, Brochado e seus associados propuseram um método de análise baseado nas classificações êmicas sobre a produção e a utilização de vasilhas contidas nos dicionários guarani-espanhol organizados pelo Pe. Montoya, S.J., na primeira metade do século XVII (Brochado; Monticelli, 1994; Brochado; Monticelli; Neumann, 1990; Noelli; Brochado, 1998; La Salvia; Brochado, 1989). Comparações entre descrições sobre a funcionalidade das vasilhas extraídas dos dicionários, de um lado, e coleções constituídas por dezenas de vasilhas arqueológicas inteiras, de outro, resultaram na convenção analítica de seis grandes classes funcionais de vasilhas utilizadas pelos Guarani. 


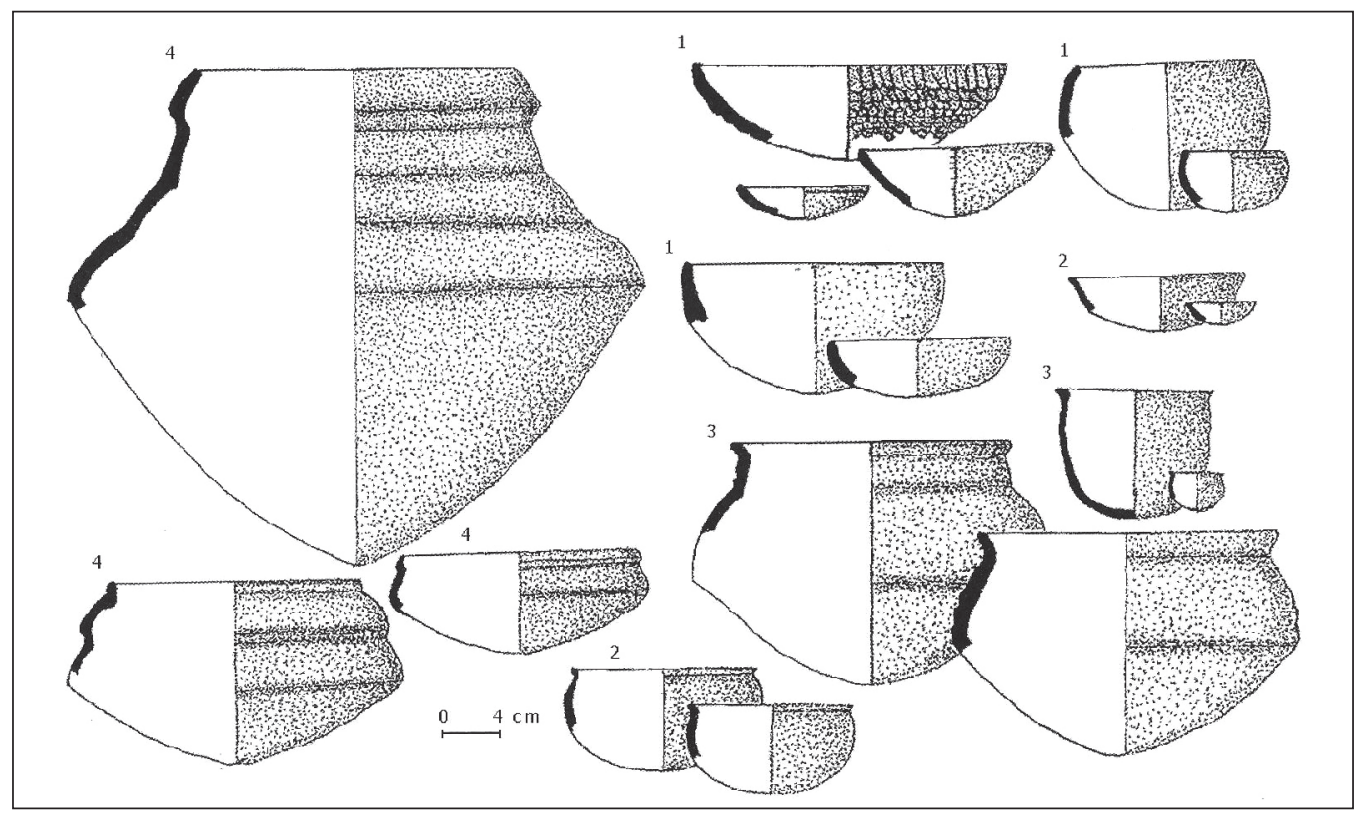

Figura 5 - Formas reconstituídas de vasilhas cerâmicas Guarani no Pantanal (Peixoto, 1998, p.79).

De acordo com Brochado e Monticelli (1994, p.110), tais classes são as seguintes: 1) a dos yapepó, termo Guarani traduzido como "panela”, caracterizada por vasilhas restringidas e restringidas independentes, com contornos inflectidos, formas conoidais e arredondadas, bojos pronunciados, bordas côncavas e bases cônicas e arredondadas, dimensões desde grandes até miniaturas, muitas vezes com corrugações na face externa, utilizadas no processamento de alimentos sólidos e líquidos junto ao fogo, através do cozimento, ou como urnas funerárias; 2) a classe dos nãetá, traduzido como "caçarola", caracterizada por vasilhas não restringidas, contorno simples, formas conoidais e elípticas horizontais, bordas diretas e bases circulares e côncavas, igualmente corrugadas e utilizadas no processamento de alimentos junto ao fogo, ou então como tampas nos enterramentos em urnas; 3) dos ñamôpyú, ou "tostador”, constituída por vasilhas não restringidas, contorno simples, formas elípticas horizontais, porém bem mais rasas que aquelas das classes dos ñaetá, bordas convexas muito baixas ou então apenas vestigiais, utilizadas para torrar farinha e assar beiju; 4) dos cambuchi, que quer dizer "talha, cântaro ou jarro", formada por vasilhas restringidas independentes, com contornos complexos, constituídos por segmentos balizados por pontos angulares salientes ou reentrantes, como carenas e ombros, não raro pintadas com motivos diversos em vermelho e/ou preto sobre engobo branco, formas conoidais, bordas cambadas, relativamente inclinadas interna, com pintura de faixa vermelha nos lábios, bases cônicas e circulares, utilizadas para preparar, servir e armazenar alimentos líquidos, inclusive as inúmeras variedades de bebidas alcoólicas fermentadas, e como urna funerária; 5 ) dos 
ñaembé, traduzida como "prato ou tigela de comer", caracterizada por vasilhas não restringidas, com contornos simples, formas elípticas horizontais, dimensões variadas, por vezes com pinturas na face interna, bordas diretas inclinadas externamente e bases arredondadas, usadas no consumo de alimentos sólidos; e, finalmente, 6) a classe dos cambuchi caguâba, entendidas como "tigelas de beber", formada por vasilhas restringidas e não restringidas, contornos simples, compostos ou complexos, tais como os cambuchi, porém em dimensões muito menores, muitas vezes com pinturas nas faces externa, interna e no lábio, formas elípticas ou conoidais, bordas diretas ou inclinadas internamente, utilizadas no consumo de alimentos líquidos e, secundariamente, como acompanhamento funerário.

Os pesquisadores citados também estabeleceram regras para a reconstituição gráfica das vasilhas pertencentes às classes dos yapepó, ñaetá e cambuchi caguâba a partir dos fragmentos de borda característicos das vasilhas dessas classes, com base na proporcionalidade conferida entre o diâmetro da boca e a altura do vasilhame nas vasilhas arqueológicas inteiras presentes nas coleções. Assim, conforme a linha de regressão apresentada por Brochado, Monticelli e Neumann (1990, p.733), por sua vez calculada a partir de uma equação regressiva, e as descrições de yapepó de dimensões variadas e determinadas contidas nos dicionários do Pe. Montoya, bordas côncavas características da classe, com diâmetro da boca entre 12 e $16 \mathrm{~cm}$, deveriam ser representadas nas reconstituições gráficas, conforme as regras de proporcionalidade estabelecidas, com alturas entre 8 e $15 \mathrm{~cm}$, sendo correspondentes às vasilhas descritas nos dicionários como yapepó myri, ou "panela pequena"; já aquelas com diâmetro bocal entre 18 e 30 $\mathrm{cm}$ teriam altura entre 18 e $30 \mathrm{~cm}$, sendo correspondentes aos yapepó boyá, ou "panela média"; e, finalmente, as bordas de yapepó maiores que $32 \mathrm{~cm}$ corresponderiam aos yapepó guaçú, ou "panela grande", e as vasilhas arqueológicas analisadas nas coleções com diâmetros de boca entre 40 e $55 \mathrm{~cm}$ apresentaram alturas entre 32 e $48 \mathrm{~cm}$. Os autores ainda notaram que os yapepó myri e as miniaturas de yapepó - quer dizer, os yapepó com diâmetros de boca inferiores a $10 \mathrm{~cm}$ - apresentavam formas arredondadas, enquanto os yapepó boyá e guaçú possuíam formas conoidais e bojo pronunciado.

Em se tratando dos nãetá e dos cambuchi caguâba, subdivididos em quatro outras classes devido às variações nas formas - sendo as mais rasas e abertas associadas aos primeiros, ou seja, aos pratos de comer, e as mais fundas e restringidas aos cambuchi caguâba, quer dizer, às tigelas de beber -, foi observado que, quanto maior o diâmetro da boca, proporcionalmente mais rasa a tigela (Brochado; Monticelli; Neumann, 1990, p.736). Assim, enquanto um ñaetá com forma elíptica horizontal, borda direta e base arredondada apresentou $8 \mathrm{~cm}$ de diâmetro de boca e $4 \mathrm{~cm}$ de altura, um outro, da mesma classe, apresentou 30 $\mathrm{cm}$ de diâmetro bocal e $12 \mathrm{~cm}$ de altura. Da mesma forma, um cambuchi caguâba com contorno complexo, forma conoidal, borda inclinada externa e base 
cônica apresentou $10 \mathrm{~cm}$ de diâmetro da boca e $6 \mathrm{~cm}$ de altura, enquanto um outro, semelhante, apresentou abertura da boca em $32 \mathrm{~cm}$ de diâmetro e altura em $12 \mathrm{~cm}$. Cabe frisar que Noelli (1999-2000, p.259) demonstrou que muitas populações indígenas falantes de línguas da família Tupi-Guarani, inclusive aquelas que ocupam a Amazônia, distantes milhares de quilômetros dos territórios Guarani, ainda usam ou então usaram termos cognatos àqueles compilados pelo Pe. Montoya quatrocentos anos atrás, o que, de certa forma, não só mostra a validade do método proposto por Brochado e colegas, mas também demonstra o quanto as classificações êmicas utilizadas estão estruturalmente enraizadas na cultura Guarani.

A padronização dos contextos arqueológicos Guarani, mesmo levando em conta as suas variações regionais, seja na cerâmica ou nos outros materiais que os constituem, figura como algo realmente impressionante, ainda mais a se julgar pela sua amplitude espaço-temporal. No passado, do mesmo modo como em relação à semelhança linguística e cultural, tal padronização foi explicada como consequência de migrações rápidas, ocorridas pouco antes da chegada dos conquistadores ibéricos, desde um centro de origem supostamente localizado entre o Paraná, o Paraguai e a Argentina. Atualmente, com o cruzamento mais sistemático e criterioso dos dados arqueológicos, linguísticos, históricos e etnográficos, acredita-se que os materiais Guarani são correlatos de processos históricos de longa duração, caracterizados pela reprodução contínua de um modo de vida característico, ou melhor, de um ethos cultural (Noelli, 1993).

De fato, as evidências indicam que os Guarani eram culturalmente prescritivos, o que teria levado não só à conquista de territórios pertencentes a outras populações com a expansão e a consolidação na região, mas também à incorporação dos membros dos grupos encontrados pelo caminho nos seus ethos. A evocação do ñande reko, uma expressão que significa algo como "o bom ou o verdadeiro modo de ser e de viver", sendo proferido sempre em situações de crise e em alusão à cultura tradicional, pode ser entendida como uma manifestação do vigor das forças prescritivas subjacentes à manutenção do ethos Guarani (Schaden, 1974). Ainda hoje presente nas vozes resignadas e reivindicativas dos Guarani, o ñande reko foi evocado frequentemente nas insurreições contra o julgo dos colonizadores europeus nos século XVI e XVII, sobretudo pelos pajés, que exortavam os índios aldeados e reduzidos a se rebelarem contra os cristãos e a voltar a viver como os seus antepassados (Monteiro, 1992).

Apesar da validade das críticas sobre o uso indiscriminado das diversas formas de analogias entre os contextos culturais dos Guarani seiscentistas e setecentistas, de um lado, e os contextos arqueológicos, de outro (Soares, 1999, 2001-2002), a utilização dos dados contidos nas fontes históricas e etnográficas escritas naquele período são fundamentais ao estudo da trajetória histórica da ocupação Guarani. Como demonstrado por muitos arqueólogos, as fontes históricas e etnográficas estão recheadas de dados ainda não completamente 
exauridos sobre organização social, parentesco, afinidade, religião, mitologia, assentamento, subsistência e tecnologia (Brochado, 1984; La Salvia; Brochado, 1989; Meliá; Saul; Muraro, 1987; Monteiro, 1994, 1992; Noelli, 1993; Schaden, 1974; Scatamachia, 1990; Soares, 1998).

Com base nesses dados, por exemplo, é sabido que os Guarani, ao menos nas vésperas da conquista, eram constituídos por milhares de pessoas, associadas umas às outras através de inúmeras parcialidades étnicas distintas, as quais muitas vezes se autoidentificavam etnicamente pelos nomes dos caciques ou chefes das famílias extensas, chamados tuvitxá. As parcialidades também podiam se autodesignar pelos topônimos das aldeias e dos territórios ocupados, respectivamente designados tekó e tekohá, ou ainda por designações que expressam alteridade em relação aos outros, como, por exemplo, avá-eté, que quer dizer gente de verdade.

A família extensa, por sua vez, era a unidade básica da morfologia social Guarani, sendo constituída, além do chefe, pela esposa ou esposas do chefe, pelos seus filhos solteiros, filhas casadas, genros, esposas dos genros, filhas solteiras e netos. Cada família extensa ocupava uma casa grande, chamada oga-guaçu, sendo que os tekó podiam ser constituídos por várias dessas, as quais podiam estar dispostas em um plano aparentemente regular, defronte umas das outras, em torno de uma espécie de praça central, por vezes cercadas por paliçadas, ou não. Os chefes também podiam deter a função de xamãs, pajés ou médicos-feiticeiros, denominados ñanderú, paí ou karaí. Estes últimos, se bem que poderiam figurar como chefes, perambulavam de aldeia em aldeia profetizando, curando e amaldiçoando, sendo amados, temidos, odiados e, não raro, mortos, sob acusação de feitiçaria. As comunidades também hospedavam cativos de guerra, destinados à execução nas praças das aldeias durante os rituais antropofágicos. Aos xamãs, chefes ou não, cabia a interlocução com o sobrenatural, efetuada através de curas, cantos, sonhos e rituais religiosos; a orientação dos membros da comunidade nos estados de crise, como na couvade, nos ritos de passagem e na morte; e a guarda dos conhecimentos mitológicos, cosmológicos, filosóficos e etno-históricos. A crença em um paraíso terreal, denominado yvy mará ey, e na pluralidade da alma, constituída pelo ayvú, a parte divina, e o atsýygua, a parte terrena ou animal, é um dos aspectos mais conhecidos da religiosidade Guarani.

As parcialidades podiam ser constituídas por vários tekó e tekohá, ao seu turno unidos por laços de consanguinidade, afinidade e reciprocidade, isto sem falar das redes de vias fluviais e caminhos terrestres, sendo os últimos chamados peabirú. A união entre vários tekohá, muitas vezes incentivada pela poligamia e, consequentemente, pela relação sogro-genro, resultava na formação dos Guará. Contudo, os tekohá, formados por um ou mais tekó, eram entidades territoriais relativamente autônomas e independentes umas das outras, ao menos em termos territoriais, políticos e econômicos. A própria autoridade dos chefes, 
fundamentada mais no prestígio social do guerreiro antropófago, na capacidade oratória e persuasiva, na qualidade de beberrão, na quantidade de esposas, filhas e genros e no poder sobrenatural do paí ou do karaí, não implicava quaisquer privilégios que os diferenciassem socialmente, sendo regulada e até contestada pelos conselhos integrados pelos outros membros influentes e prestigiosos da comunidade, como os chefes das outras famílias extensas, os xamãs e os outros guerreiros.

A autoridade dos chefes se fazia mais presente nas questões envolvendo a comunidade como um todo, como na organização dos trabalhos coletivos, chamados putxiran, e nas relações com outras comunidades, fossem essas pacíficas ou não. Muitas vezes, tendo em vista a realização de tarefas como derrubadas, queimadas, construções de facilidades, organização de rituais e beberagens, fortificações e mudanças de aldeia, os putxiran requeriam grande número de pessoas, as quais apenas podiam ser mobilizadas por chefes que detivessem muito prestígio, capazes de oferecer festas regadas a comida e bebida durante a realização dos trabalhos. As relações com outras comunidades, fossem essas Guarani ou não, podiam ser pacíficas, como no caso dos tekohá unidos, ou violentas, como no caso das guerras intestinas motivadas por vinganças e pela captura de cativos.

Se aos homens cabiam os papéis de chefes, xamãs, guerreiros e cativos, às mulheres recaíam grande parte das atividades de subsistência, como o cultivo dos roçados e a confecção dos utensílios cerâmicos. Como demonstrado pelo estudo etnoarqueológico sobre assentamento e subsistência desenvolvido por Noelli (2003), os dados contidos nas fontes históricas e etnográficas indicam que os Guarani eram consideravelmente autônomos em relação ao meio e não apresentavam restrições alimentares. A dieta era garantida pelas centenas de espécimes vegetais cultivadas e/ou manejadas por todo o tekohá, tanto trazidas da região amazônica quanto incorporadas nas áreas colonizadas, e complementada por atividades de caça, pesca e coleta, inclusive de insetos. As áreas de cultivo e de manejo, constituídas por plantas alimentícias, medicinais e utilizadas enquanto matérias-primas na confecção de artefatos diversos, estavam dispostas tanto no entorno imediato dos tekó quanto ao longo dos caminhos abertos pela floresta. A caça e a pesca eram realizadas através do uso de diversas armadilhas, muitas delas um tanto quanto engenhosas, sendo que na pesca também eram utilizados ictiotóxicos.

As terras indígenas Kadiwéu e Lalima, por exemplo, estão situadas em trechos da região historicamente conhecida como Itatim, a qual, por sua vez, era ocupada por populações indígenas diversas, mas principalmente pelos Guarani-Itatim, descritos etnicamente como Garambaré, Ñuara, Cutaguá e Temiminós (Gadelha, 1980; Monteiro, 1994; Sanchez Labrador, 1910). Acerca desses índios, o Pe. Ferrer, em sua ânua de 1633, escreveu o seguinte (Cortesão, 1952, p.30-1): 
[...] estos Itatines son de buen natural, y no difieren de los demas guaranis, sino que tienen mas trato y policia... y tambien en la lengua tienen alguma diferencia... aunque poca acercandose... al lenguaje Tupi, de suerte que algunos dizem que non son... Guaranis ni Tupis... sino... una nacion entremedia... que llaman Temiminos. Son agiles para la caça y su comum exercicio de recreacion es llevar um palo a cuestas [...] sus armas son arco y flecha y macana, y... tienen lanças. en... guerra emponçoñan las puntas de sus flechas [...] son destros a corrir caballos [...] Comumente cada indio no tiene mas de una mujer.. y no parece que... conoscan la perpetuidad del matrimonio [...] las mujeres... tienen todos los braços y piernas y casi todo el cuerpo listado [...] Todos estos Itatines reconocen a un cacique que se llama Nanduabuçu como a principal de todos, el qual dize que todos los... Guaranis que ay desde... Assumpcion para aca son... sus vasallos, y aun los que estan adelante [...] viven en pueblos grandes o chicos, pero por la mayor parte... son cerca de cien familias, y algunos ay de docientas $y$ aun mas [...]

Depois do esgotamento da mão de obra Guarani em torno de Assunção, ainda na segunda metade do século XVI, parcialidades dos Itatim foram aldeadas e encomendadas pelos espanhóis nos rio Ypané e Jejuý. Os espanhóis tentaram assegurar a posse de toda a região onde atualmente se encontra o Mato Grosso do Sul com a fundação da cidade de Santiago de Xerez, erigida inicialmente nas proximidades da confluência do Ivinhema com o Paraná, em 1593, porém posteriormente transladada para a margem direita do médio Aquidauana (Martins, 2002b). Com o acirramento do bandeirantismo, no início dos seiscentos, e com a destruição do Guairá, em 1628, jesuítas e bandeirantes se voltam para o Itatim, com vistas nos últimos povos Guarani da região.

A despeito das experiências prévias com os Itatim aldeados anteriormente, os jesuítas começaram a catequese no Itatim em 1632, com a redução de índios Nuara, que ocupavam o rio Miranda, na missão de San Jose de Yacaroy (Gadelha, 1980; Sousa, 2002). Todavia, logo depois, com o apoio dos colonos de Xerez, uma bandeira comandada por Ascenso Quadros assaltou várias aldeias na região, causando uma série de prejuízos. Mesmo assim, a obra missioneira continuou e, depois de muitos reveses, logrou algum progresso, até que, em 1647, Antônio Raposo Tavares, acompanhado por André Fernandes, desestabilizou as Missões do Itatim.

Os Itatim não levados para São Paulo na condição de escravos dos portugueses acompanharam os jesuítas para Assunção e, mais tarde, para a Mesopotâmia argentina (Monteiro, 1994, p.239). Outros ainda se refugiaram nas matas submontanas da serra de Maracajú, de onde assistiram à expansão dos Mbayá-Guaikurú e dos Guaná sobre os seus antigos territórios. Ainda hoje os Guarani são a população indígena mais numerosa em Mato Grosso do Sul, onde as parcialidades Nandeva e Kaiowá somam quase trinta mil pessoas, dispersas em reservas indígenas localizadas na região sul do estado, principalmente na fronteira com a Paraguai (Instituto Socioambiental, 2001-2005). 


\section{Os povos Aruak}

Assim como os Tupi, os Aruak, também chamados Maipure, eram populações agricultoras, viviam em grandes aldeias, estavam distribuídas em várias parcialidades étnicas, ocupavam territórios dispersos por uma área bastante ampla e se originaram culturalmente na Amazônia, porém no mais se diferenciavam daqueles em quase todos os aspectos. Em termos gerais, a maior parte das populações Aruak, consolidadas em territórios formados na costa da Flórida, nas ilhas caribenhas, nas floretas da Amazônia e nas terras baixas do Pantanal e do Chaco, viviam em aldeias circulares, divididas em metades, dispostas em torno de uma praça central, apresentavam estratificação social complexa e um grau de sedentarismo elevado. O próprio termo Cacique, diga-se de passagem, aplicado aos chefes indígenas em geral, deriva da palavra Cacib, denominação dada ao chefe dos Taino, populações Aruak encontradas por Colombo na ilha de Santo Domingo, em 1492 (Fausto, 2005). Além desses traços, as populações de matriz cultural Aruak também apresentam semelhanças tecnológicas entre si, inclusive em se tratando da cerâmica (Heckenberger, 2001, 2002, 2005; Neves, 2000; Rouse 1992).

As questões sobre o centro de origem e as rotas de expansão Aruak são tão nebulosas quanto aquelas relativas aos Tupi, porém há certa inclinação da maior parte dos arqueólogos e linguistas em atribuir a região entre o alto rio Negro e o alto rio Orinoco, na fronteira entre Venezuela e Brasil, como provável centro de dispersão dessas populações (Heckenberger, 2005; Urban 1992). De acordo com Heckenberger (2002, p.106), os Aruak teriam partido da área de origem para centros de dispersão secundários, tais como a Amazônia central e o alto Madeira, de onde teriam se espalhado, através de diversas rotas de expansão, para os locais onde foram encontrados pelos conquistadores europeus. Acerca da origem e das rotas de expansão das populações Aruak ao sul da Amazônia, o mesmo arqueólogo citado destacou, em um trabalho anterior (Heckenberger, 2001, p.30-1), o seguinte:

Embora também não me proponha aqui desenvolver uma discussão geral sobre a origem ou antiguidade das línguas Maipure no sul da Amazônia (bauré, mojo, piro, chané, terena [guana], pareci, e as do Alto Xingú), gostaria de destacar que é provável que todas - ou a maioria - possam ser remetidas a uma antiga migração, ou série de migrações, para a região do Alto Madeira, de onde posteriormente se expandiram para oeste (Acre e Perú), para sul (terras baixas da Bolívia) e para leste (Periferia Meridional). Os terena (guana) e os chané limitam as extensões desse processo ao sul, enquanto os pareci e os alto-xinguano limitam-nas a leste.

Os contextos arqueológicos associados à indústria cerâmica Barrancoide-Saladoide detectados na Amazônia, datados em até três mil anos ap, não raro circundados por valas de caráter defensivo escavadas em torno de sítios com grandes dimensões, foram associadas com populações Aruak (Heckenberger, 2005; Neves, 1999a, 1999b, 2000, 2006). No alto Xingú, enquanto as primeiras 
ocupações Aruak datam em mil anos ap, a construção das fortificações foram datadas entre seiscentos e quatrocentos anos ap, mesmo período da chegada das populações de matriz cultural Karib na área (Heckenberger, 2001).

No Pantanal e no Chaco, as populações de matriz cultural Aruak foram encontradas pelos europeus na região do alto Paraguai, na área fronteiriça entre o Mato Grosso e a Bolívia, e no arco setentrional do Chaco, nas terras baixas ao longo das fronteiras entre Paraguai, Bolívia e Brasil (Métraux, 1946). Além do mais, há um debate sumamente interessante sobre a filiação Aruak dos Chaná-Timbú e da associação destes com a Entidade Goya-Malabrigo.

No alto Paraguai, os Aruak eram constituídos pelos Orejones, Xaray e alguns grupos Chiquitanos, tais como os Saraveka, Koraveka e Kuruminaca. Ainda foram encontrados grupos Chané no alto Paraguai ao tempo dos primeiros contatos com os conquistadores, porém esses haviam fugido dos Chiriguano, povos Guarani estabelecidos nos sopés andinos que os tomavam como cativos.

Na região de Cáceres (MT), as populações Aruak do alto Paraguai foram associadas à Tradição Descalvados, por sua vez caracterizada por sítios de grandes dimensões, constituídos por muitos fragmentos de vasilhas, líticos lascados e polidos, montículos artificiais, sepultamentos humanos, datados entre 1.500 e trezentos anos ap (Martins; Kashimoto, 1999b; Migliacio, 2000, 2001-2002, 2006). As vasilhas cerâmicas apresentam formas abertas e fechadas, contornos simples, infletidos, compostos e complexos, formas esféricas, semiesféricas, ovais verticais, semiovais verticais e semielípticas horizontais, tais como pratos, alguns muito rasos, tigelas, panelas, jarros e silos, adequadas ao consumo, processamento e armazenagem de alimentos. Algumas vasilhas fechadas com formas ovais e contornos inflectidos, compostos e complexos, impressionam pelas dimensões avantajadas, com capacidades volumétricas superiores a 160 litros. Destacam-se também a ocorrência de pinturas geometrizadas sobre engobo vermelho, constituídas por linhas, faixas, pontos, cruzes e triângulos combinados, e a presença de alças e apêndices de suspensão. Entre os antiplásticos aprecem cacos de cerâmica e conchas trituradas. A manufatura era acordelada, porém algumas vasilhas possuíam bordas e alças de suspenção modeladas. A queima incompleta predominava, porém a frequência de fragmentos oxidados é significativa. Também são achados outros artefatos cerâmicos nos contextos Descalvados, entre os quais se destacam estatuetas antropomórficas e zoomórficas modeladas.

Nas terras baixas do arco setentrional do Chaco, na região fronteiriça entre Bolívia, Paraguai e Brasil, havia duas grandes populações de matriz cultural Aruak no século XVI, falantes de línguas Chané, de família linguística Chané-Guaná: os Chané propriamente, que ocupavam o segmento oriental da área, e os Gua-ná, que estavam estabelecidos no segmento ocidental (Métraux, 1946). Os Guaná, assim como os Chané, se autodenominavam Chané, que significa "gente”, e estavam constituídos por várias parcialidades distintas (Schuch, 1995). Algumas dentre essas, sobretudo os Kinikinao e Laiana, eram aliadas dos Mbayá 
e migraram com esses para o Pantanal, nos século XVI e XVII, assentando-se inicialmente na região de Corumbá e, posteriormente, na região de Miranda. Outras, como os Terena, não eram tão aliadas dos Mbayá, mas, assim como esses e muitas das populações Aruak do arco ocidental do Chaco, se estabeleceram no que hoje é o Mato Grosso do Sul na época colonial, depois que o antigo Itatim foi abandonado pelos Guarani e espanhóis.

De acordo com os estudos de Cardoso de Oliveira (1968, p.17-35, 1976, p.41-53), ao tempo dos primeiros contatos com os europeus, ocorridos no século XVIII, a cultura tradicional dos Terena, também referidos como Etelena ou Etelenoé, era caracterizada pela presença de aldeias circulares, divididas em metades e estratificadas socialmente entre classes endogâmicas. Indivíduos que adquirissem prestígio, sobretudo por meio da guerra, podiam ascender às classes superiores, deixando de ser caracterizado como whaherê e caati, ou seja, "gente comum" e "cativo", e passando a ser reconhecido como xuna-xati. Os caati, geralmente originários de outras parcialidades étnicas, nunca poderiam ascender à classe dos naati, a mais privilegiada, mas apenas à dos whaherê, o segmento intermediário. Os whaherê, por sua vez, poderiam vir a ser reconhecidos como naati. Os xamãs, também designados pelo termo purungueiro, eram chamados koixomuneti. Ainda hoje existe uma localidade bastante povoada na TI Cachoeirinha, ou Bookoti, uma das mais tradicionais dos Terena, chamada Argola, em alusão àquela que pode ser considerada como uma das últimas aldeias circulares dos Guaná em Miranda (Castelnau, 1949).

Entre fins dos setecentos e inícios dos oitocentos, a região de Miranda era ocupada por populações Guaikuru, como os Cotoguéu, e Guaná, sobretudo Laiana e Terena. Talvez essas tenham sido as primeiras populações a se estabelecer na região depois do abandono Guarani, a qual deixou de ser referenciada como Itatim e passou e ser denomina de Lauiad, que em Mbayá quer dizer “campo belo" (Taunay, 1997, p.48). Até mesmo o rio Miranda, então referido como Mbotetey ou Cayy, passou a ser chamado de Mondego (Martins, 2002b). Os Mbayá e Guaná pelejaram contra espanhóis e portugueses pelo domínio territorial da região durante todo o século XVIII e grande parte do XIX (Costa, 1999). Vencida a resistência indígena, os portugueses, consolidados nas áreas auríferas e diamantíferas de Cuiabá e Mato Grosso, se estabeleceram definitivamente nas regiões de Corumbá e Miranda na segunda metade do século XVIII, com a fundação do Forte Coimbra e do Presídio de Miranda (Esselin, 2000). Esta última fortificação, construída de taipa e guarnecida com algumas poucas dezenas de soldados, foi destruída quando os paraguaios invadiram o então sul de Mato Grosso e deflagraram a Guerra do Paraguai. Suas ruínas são uma incógnita à Arqueologia Regional, haja vista que ainda não foram detectadas.

A princípio, a relação entre os índios e os praças que formavam o contingente do Presídio era amistosa, porém na medida em que a colonização avançou, sobretudo com a primeira frente de expansão agropastoril vinda de Minas 
Gerais, o trabalho dos índios começou a ser explorado nas fazendas recém-formadas (Azanha, 2005; Cardoso de Oliveira, 1968, 1976, 2002). O processo de fragmentação territorial e cultural aí iniciado se exacerbou depois da Guerra do Paraguai, com o loteamento dos territórios e a exploração compulsiva da mão de obra indígena. Posteriormente, no início do século XX, os povos indígenas em Miranda, formados principalmente por índios Guaikuru, Terena, Kinikinao e Laiana, foram libertos do cativeiro nas colônias de fazenda e confinados em reservas indígenas, onde começaram a ser tutelados pelo Serviço de Proteção aos Índios (SPI).

Na região de Corumbá, foram detectados os sítios históricos oitocentistas das missões de Nossa Senhora do Bom Conselho e Nossa Senhora da Misericórdia, fundadas por padres franciscanos junto aos índios Kinikinao, assentados na área, em conjunto com os Guaikuru, desde o século XVIII (Schmitz et al., 1998). Com a Guerra do Paraguai e os tumultos causados no sul do Mato Grosso, os Kinikinao se dispersaram em direção à região de Miranda, onde se assentaram nas margens do cór. Agaxi (Cardoso de Oliveira, 1976, p.64). Posteriormente, em 1925, esses Kinikinao foram levados à Terra Indígena Lalima pelo SPI, onde passaram a conviver com os Guaikuru, já estabelecidos na área desde a primeira metade do século XIX, e com os Terena e Laiana, igualmente trazidos pelo SPI (Steinen, 1940).

Os correlatos arqueológicos do processo de formação do contexto etnográfico atual em Lalima, cujos significados etno-históricos encontram-se na identidade cultural, na memória coletiva e na territorialidade dos Guaikuru, Terena, Kinikinao e Laiana que a constituem, foram registrados por Bespalez $(2013,2014)$. Trata-se de moradias abandonadas, marcos territoriais e feições naturais, como árvores, cursos d'água, matas e morros, carregados de significados históricos, mágicos, míticos e religiosos, peculiares da cultura indígena em Lalima, utilizados cosmográfica e recursivamente na percepção da paisagem e na manifestação de territorialidade. Eremites de Oliveira (2011) registrou sítios e lugares significativos semelhantes no seu estudo sobre o sistema de assentamento e o processo de territorialização entre os Terena na Terra Indígena Buriti, situada na serra de Maracajú, entre os municípios de Sidrolândia e Dois Irmão do Buriti (MS).

Os contextos arqueológicos formados com a ocupação dos Aruak em Mato Grosso do Sul ainda não são conhecidos, todavia é possível que eles se confundam com os materiais inseridos na Tradição Pantanal, principalmente em se tratando das fases mais recentes, haja vista que muitas dessas populações eram aliadas dos Mbayá-Guaikuru desde os tempos do Chaco. Por outro lado, tendo em vista as descobertas realizadas com as pesquisas nos contextos arqueológicos da Tradição Descalvados, no alto Paraguai, nada impede que populações de matriz cultural Aruak, aparentadas dos Guaná ou não, tenham se estabelecido nas regiões de Corumbá e Miranda em período pré-colonial. 
Os Terena ainda continuam confeccionando cerâmica em muitas das suas aldeias. Assim como no que se refere aos Kadiwéu, a tecnologia cerâmica Terena, reproduzida socialmente nos moldes atuais ao menos desde o fim da Guerra do Paraguai, também não foi alvo de pesquisas etnoarqueológicas sistemáticas, porém Cardoso de Oliveira (2002, p.237) oferece uma descrição sumária do fluxo de produção das vasilhas. Vale frisar que a tinta branca utilizada sobre engobo vermelho na decoração das faces e dos lábios no vasilhame Terena, obtida através da decantação de certo tipo específico de argila, por vezes apresenta-se com uma densidade tão alta que até chega a lembrar dos apliques de filigranas que decoram as faces externas e os lábios das vasilhas da Tradição Pantanal, sobretudo em se tratando da Fase Jacadigo. O pupuí, uma vasilha fechada, com alça de suspensão, utilizada para armazenar e servir líquidos, ao lado das estatuetas zoomórficas inspiradas na fauna do Pantanal, vendidos às centenas entre os turistas que visitam a região, são os objetos cerâmicos mais conhecidos dos Terena.

\section{Conclusão}

Apesar do caráter ainda incipiente da arqueologia no Pantanal, os dados obtidos até o momento permitem inferir que a trajetória histórica e cultural da ocupação indígena na região é longa, diversa e complexa. Desde a chegada dos caçadores-coletores no Pleistoceno, muitas transformações culturais ocorreram entre as populações indígenas que se assentaram na região. Entre essas, destacam-se o estabelecimento dos caçadores-coletores, a consolidação dos povos ceramistas no Pantanal, a expansão das populações culturalmente originadas no Brasil Central e na Amazônia, a configuração do mosaico cultural registrado a partir do século XVI e os impactos do colonialismo. Certamente, com o surgimento de novos dados, outras questões poderão ser somadas àquelas já reunidas, ampliando, diversificando e complicando a história cultural da ocupação indígena no Pantanal.

\section{Referências}

AB'SÁBER, A. N. Brasil: paisagens de excę̧̃̃o (O Litoral e o Pantanal Mato-Grossense - Patrimônios Básicos). Cotia: Ateliê, 2006. p.9-78.

ALCONINI MCELHINNY, S.; RIVERA CASANOVAS, C. La tradicion ceramica "Estampada e Incisa de Bordes Doblados" en la vertiente oriental de los Andes: un caso de interaccion e influencia desde las zonas bajas. In: ORTIZ, G; VENTURA, B. (Ed.) La mitad verde del mundo andino. Investigaciones arqueológicas en la vertiente oriental de los Andes y las Tierras Bajas de Bolivia y Argentina. San Salvador de Jujuy: Universidad Nacional de Jujuy, 2003. p.153-77.

ALMEIDA, F. O. O complexo Tupi da Amazônia Oriental. 2008. Dissertação (Mestrado em Arqueologia) - Museu de Arqueologia e Etnologia, Universidade de São Paulo. São Paulo, 2008.

ALMEIDA SERRA, R. F. Continuação do Parecer sobre os índios Uaicurús, Guanás, etc. Que se começou a publicar na Revista n.26, pag. 204 do tomo $7^{\circ}$, etc. Manuscrito 
original do Sr. Dr. Tenente-coronel Jardim. Revista Trimestral de História e Geografia ou Jornal do Instituto Histórico e Geográphico Brasileiro, Rio de Janeiro, v.XIII, p.348$96,1845$.

AMILCAR RODRÍGUEZ, J. Arqueología del sudeste de Sudamérica. In: MEGGERS, B. J. Prehistoria sudamericana: nuevas perspectivas. Washington: Taraxacum, 1992.

ANTHONY, D. W. The horse, the Wheel, and language. How Bronze Age riders from the Eurasian steppes shaped the modern world. Princeton: Princeton University Press, 2007.

AZANHA, G. As terras indígenas Terena no Mato Grosso do Sul. Revista de Estudos e Pesquisas, Brasília, v.2, n.1, p.61-111, 2005.

BASTOS, U. R. de A. Expansão territorial do Brasil colônia no vale do Paraguai. 1972. Tese (Doutorado em História). Faculdade de Filosofia, Letras e Ciências Humanas, Universidade de São Paulo. São Paulo, 1972.

BERRA, J. C.; DeBLASIS, P. A cerâmica de Ferraz Egreja. In: VILHENA-VIALOU, A. V. Pré-história do Mato Grosso. São Paulo: Edusp, 2006. p.191-202. v.2: "Cidade de Pedra”.

BESPALEZ, E. Levantamento arqueológico e etnoarqueologia na Aldeia Lalima, Miranda/MS: um estudo sobre a trajetória histórica da ocupação indígena regional. 2009. Dissertação (Mestrado em Arqueologia) - Museu de Arqueologia e Etnologia, Universidade de São Paulo. São Paulo, 2009.

Levantamento arqueológico na Aldeia Lalima, Miranda/MS: uma contribuição ao estudo da trajetória histórica da ocupação indígena regional. Revista de Arqueologia, São Paulo, v.23, n.2, p.118-43, 2010.

Arqueologia e etno-história na Terra Indígena Lalima. Revista de Arqueologia, São Paulo, v.26, n.1, p.82-90, 2013.

As formações territoriais na Terra Indigena Lalima, Miranda/MS: os significados históricos e culturais da Fase Jacadigo da Tradição Pantanal. 2014. Tese (Doutorado em Arqueologia) - Museu de Arqueologia e Etnologia, Universidade de São Paulo. São Paulo, 2014.

BOGGIANI, G. Compendio de etnografía paraguaia moderna. Revista Instituto Paraguayo, Assunción, v.3, 1900.

BONOMO, M. et al. A model for the Guaraní expansion in the La Plata basin and litoral zone of Southern Brazil. Quaternary International, v.356, p.54-73, jan. 2015.

BRASIL. MINISTÉRIO DAS MINAS E ENERGIA. Secretaria Geral. Projeto RADAMBRASIL. 1982 Folha SF 21 Campo Grande; geologia, geomorfologia, pedologia, vegetação e uso potencial da terra. Rio de Janeiro, 1982.

BROCHADO, J. P. Migraciones que difundieron la tradicion alfarera Tupiguarani. Relaciones, La Plata, v.7, p.7-39, 1973.

An ecological model of the spread of pottery and agriculture into Eastern South America. 1984. Thesis (PhD. in Anthropology) - University of Illinois. Urbana-Champaing, 1984.

BROCHADO, J. P.; MONTICELLI, G.; NEUMANN, E. S. Analogia etnográfica na reconstrução gráfica das vasilhas Guarani arqueológicas. Véritas, Porto Alegre, v. 35, p. 727-743, 1990. 
BROCHADO, J. P.; MONTICELLI, G. Regras práticas na reconstrução gráfica das vasilhas de cerâmica Guarani a partir dos fragmentos. Estudos Ibero-Americanos, Porto Alegre, v.2, p.107-18, 1994.

BUENO, L. M. R. Variabilidade tecnológica nos sítios líticos da região do Lageado, médio rio Tocantins. Revista do Museu de Arqueologia e Etnologia, São Paulo, Suplemento 4, 2007.

CABEZA DE VACA, A. N. Naufragios y comentarios. Madrid: Edción de Roberto Ferrero, 1985.

CARDOSO de OLIVEIRA, R. Urbanização e tribalismo. Rio de Janeiro: Zahar, 1968. . Do índio ao bugre: o processo de assimilação dos Terena. 2.ed. Rio de Janeiro: Museu Nacional, 1976.

Os diários e suas margens. Brasília: UnB, 2002.

CARVALHO, S. M. S. Chaco: encruzilhada de povos e "melting pot" cultural, suas relações com a bacia da Paraná e o sul mato-grossense. In: CARNEIRO DA CUNHA, M. História dos indios no Brasil. São Paulo: Companhia das Letras, 1992. p.457-74.

CASTELnAU, F. de. Expedições às regiões Centrais da América do Sul. São Paulo: Nacional, 1949.

CERRUTI, C. Entidades culturales presentes en la Cuenca de Paraná Medio (margem entrerriana). Mundo de Antes, n.3, p.111-35, 2003.

CERRUTI, C.; GONZÁLEZ, M. I. Modos de vida vinculados con ambientes acuáticos del Nordeste y Pampa Bonaerense de Argentina. Relaciones de la Sociedad Argentina de Antropología, Buenos Aires, n.33, p.101-40, 2007.

CHMYZ, I. Dados arqueológicos do baixo rio Paranapanema e alto rio Paraná. In: PRONAPA. Resultados preliminares do $5^{\circ}$ ano. Belém: Museu Goeldi, 1974. p.67-90.

Estado atual das pesquisas arqueológicas na margem esquerda do rio Paraná. Estudos Brasileiros, Curitiba, v.8, n.13, p.5-39, 1982.

Sétimo relatório do Projeto Arqueológico Itaipu. Curitiba: Itaipu/Iphan, 1983.

CORTESÃO, J. (Org.) Manuscritos da Coleção de Angelis. Jesuítas e bandeirantes no Itatim (1596-1760). Rio de Janeiro: Biblioteca Nacional, Divisão de Obras Raras e Publicações, 1952.

COSTA, M. F. História de um país inexistente: o Pantanal entre os séculos XVI e XVIII. São Paulo: Kosmos, 1999.

CRUZ, D. G. Lar, doce lar? Arqueologia Tupi na bacia do Ji-Paraná (RO). 2008. Dissertação (Mestrado em Arqueologia) - Museu de Arqueologia e Etnologia, Universidade de São Paulo. São Paulo, 2008.

DIAS JUNIOR, O; CARVALHO, E. A fase Piumhy: seu reconhecimento arqueológico e suas relações culturais. Clio, Recife, v.5, p.5-43, 1982.

EREMITES DE OLIVEIRA, J. Guató: argonautas do Pantanal. Porto Alegre: EDIPUC/RS, 1996.

Ambiente e cultura no contexto da ocupação indígena da planície de inundação do Pantanal. Fronteiras, Dourados, v.3, n.6, p.9-34, jul./dez. 1999. 
EREMITES DE OLIVEIRA, J. A história indígena em Mato Grosso do Sul, Brasil: dilemas e perspectivas. Territórios e Fronteiras, Cuiabá, v.2, n.2, p.115-24, jul./dez. 2001 a.

Acuri, a palmeira dos índios Guató. Suplemento Antropológico, Asunción, v.36, n.1, p.355-86, 2001b.

Da pré-história à história indígena: (Re) pensando a arqueologia e os povos canoeiros do Pantanal. Revista de Arqueologia, São Paulo, v.16, p.71-86, 2003.

Arqueologia das Sociedades Indigenas no Pantanal. Campo Grande: Oeste, 2004.

Os primeiros passos em direção a uma arqueologia pantaneira: de Max Schmidt e Branka Susnik a outras interpretações sobre os povos indígenas nas terras baixas do Pantanal. Revista de Arqueologia, v.20, p.83-115, 2007.

Sistema de assentamento e processo de territorialização entre os Terena da Terra Indígena Buriti, Mato Grosso do Sul, Brasil. Habitus, v.9, n.1, p.169-99, 2011.

. A história indígena no Brasil e em Mato Grosso do Sul. Espaço Ameríndio, Porto Alegre, v.6, n.2, p.178-218, 2012.

EREMITES DE OLIVEIRA, J.; VIANA, S. A. O Centro-Oeste antes de Cabral. Revista USP, São Paulo, n.44, p.142-89, 1999-2000.

ESSELIN, P. A gênese de Corumbá: confluência das frentes espanhola e portuguesa em Mato Grosso (1536-1778). Campo Grande: UFMS, 2000.

ETCHEVARNE, C. A ocupação humana no Nordeste brasileiro antes da colonização portuguesa. Revista USP, São Paulo, v.44, p.12-41, 1999-2000.

FACCIO, N. B. Arqueologia dos cenários das ocupações horticultoras da Capivara, baixo Paranapanema/SP. 1998. Tese (Doutorado em Arqueologia) - Museu de Arqueologia e Etnologia, Universidade de São Paulo. São Paulo, 1998.

FAUSTO, C. Os indios antes do Brasil. 3.ed. Rio de Janeiro: Zahar, 2005.

FELICÍSSIMO, M. P. et al. Estudos arqueométricos de cerâmicas indígenas pré-coloniais das lagoas do Castelo e Vermelha, localizadas no Pantanal sul-mato-grossense. Canindé, v.4, p.325-68, 2004.

FERREIRA, A. R. A expedição philosophica pelas capitanias do Pará, Rio Negro, Mato Grosso e Cuyabá. In: SOARES, J. P. M.; FERRÃO, C. Viagem ao Brasil de Alexandre Rodrigues Ferreira. s. 1.: Kapa, 1971.

FIGUTTI, L. Os sítios a céu aberto na Fazenda Verde. In: VIALOU, A. V. Pré-história do Mato Grosso. São Paulo: Edusp, 2006. p. 211-216. v. 2: "Cidade de Pedra".

GADELHA, R. M. A. F. As missões jesuiticas do Itatin: um estudo das estruturas sócio-econômicas coloniais, séc. XVI e XVII. Rio de Janeiro: Paz e Terra, 1980.

GIRELLI, M. Lajedos com gravuras na região de Corumbá, MS. 1994. Dissertação (Mestrado em História) - Universidade do Vale do Rio dos Sinos. São Leopoldo, 1994.

GÓMES PERASSO, J. A. Estudios arqueológicos en el Paraguay: análisis interpretativo. Etnografía Paraguaya, Assunción, v.1, n.2, p.1-32, 1978.

GUZMAN, R. D. Argentina. Historia del descubrimiento, conquista y poblacion del rio de la Plata. Buenos Aires: Imprenta y Libraria de Mayo, 1882. 
HECKENBERGER, M. J. War and peace in the shadow of empire: sociopolitical change in the upper Xingu of Southeastern Amazonia, A.D. 1400-2000. 1996. Thesis (PhD. in Anthropology) - University of Pittesburgh. Pittesburgh, 1996;

Estrutura, história e transformação: a cultura xinguana. In: FRANCHETO, B.; HECKENBERGER, M. Os povos do alto Xingu: história e cultura. Rio de Janeiro: UFRJ, 2001.

Rethinking the arawakan diaspora: hierarchy, regionality, and the Amazoniam formative. In: HILL, D.; SANTOS-GRANERO, F. Comparative Arawakan history: rethinking language family and culture area in Amazonia. Urbana: University of Illinois, 2002.

The ecology of power: culture, place, and personhood in the southern Amazon, AD 1000-2000. New York: Routledge, 2005.

HECKENBERGER, M.; NEVES, E.; PETERSEN, J. De onde surgem os modelos?: a arqueologia da origem dos Tupi e Guarani. Revista de Antropologia, São Paulo, v.41, n.l, 1998.

HEMMING, J. Ouro vermelho: a conquista dos índios brasileiros. São Paulo: Edusp, 2007.

HENRIQUES, G.; COSTA, F.; KOOLE, E. O alto São Francisco e o mito dos Cataguá: contribuições para a história indígena em Minas Gerais. Revista do Museu de Arqueologia e Etnologia, São Paulo, n.14, p.195-208, 2004.

HERBERTS, A. L. Os Mbayá-Guaicuru: área, assentamento, subsistência e cultura material. 1998. Dissertação (Mestrado em História) - Universidade do Vale do Rio dos Sinos. São Leopoldo, 1998.

HODDER, I. Archaeology as Long-Term History. Cambridge: Cambridge University Press, 1987.

INSTITUTO SOCIOAMBIENTAL. Povos indígenas no Brasil. São Paulo: ISA, 2001 2005.

JONES, S. The archaeology of ethnicity. London: Routledge, 1997.

KAIFLER, C. Los Petroglifos de Capinsal, Depto. de Santa Cruz, Bolivia. Sociedad de Investigación del Arte Rupestre de Bolivia, n.13, p.53-63, 1999.

El Sitio de Petroglifos "Canõn de los Tocos”, Departamento de Santa Cruz, Bolivia. Contribuciones al Estudio del Arte Rupestre Sudamericano Sociedad de Investigación del Arte Rupestre de Bolivia, n.6, p.67-93, 2002.

Los Petroglifos del sitio La Cruz, Mutúm, Depto. de Santa Cruz, Bolivia.

Sociedad de Investigación del Arte Rupestre de Bolivia, n.20, p.18-45, 2006.

KASHIMOTO, E. M. Variáveis ambientais e arqueologia no Alto Paraná. 1997. Tese (Doutorado em Arqueologia) - Faculdade de Filosofia, Letras e Ciências Humanas, Universidade de São Paulo. São Paulo, 1997.

KASHIMOTO, E. M.; MARTINS, G. R. Panorama arqueológico da margem direita do rio Paraná, MS: do povoamento por caçadores-coletores a índios Guarani coloniais. Clio, Recife, v.14, p.299-315, 2000.

A problemática arqueológica da tradição cerâmica Tupiguarani em Mato 
Grosso do Sul. In: PROUS, A.; LIMA, T. A. (Org.) Os ceramistas Tupiguarani. Brasília: Iphan, 2008.

LA SAlVIA, F., BROCHADO, J. P. Cerâmica Guarani. Porto Alegre: Posenato Arte e Cultura, 1989.

LAPONTE, D.; ACOSTA, A. Estado actual y perspectivas de la arqueologia de la "tradicion Tupiguarani” em Argentina. In: PROUS, A.; LIMA, T. A. Os ceramistas Tupiguarani. Brasília: Iphan, 2008.

LÉVI-STRAUSS, C. Tristes trópicos. Lisboa: Edições 70, 1986.

LOZANO, P. Historia de la Compañia de Jesús en la Província del Paraguay. Madrid: Imprenta de la viuda de Manoel Fernandez y del Supremo Consejo de la Inquisición, 1754-1755.

MAgAlHãeS, N. W. Conheça o Pantanal. São Paulo: Terragraph, 1992.

MARTINS, G. R. Relatório de registro de sítios arqueológicos em Rio Negro-MS. Fronteiras, Dourados, v.2, n.4, p.223-50, 1998.

2002a.

Breve painel etno-histórico de Mato Grosso do Sul. 2.ed. Campo Grande: UFMS,

- Santiago de Xerez: uma problemática para a arqueologia histórica. Historia Paraguaya, Assunción, v.XLII, 2002 b.

2003.

Arqueologia do planalto Maracaju-Campo Grande. Campo Grande: UFMS,

MARTINS, G. R.; KASHIMOTO, E. M. Resgate arqueológico na área do gasoduto Bolivia/Brasil em Mato Grosso do Sul. Campo Grande: UFMS, 1999a.

Arqueologia do contexto do rio Jauru (MT) impactado pelo gasoduto Bolívia-Mato Grosso. Revista do Museu de Arqueologia e Etnologia, São Paulo, n.10, p.121$43,1999 b$.

12.000 anos: arqueologia do povoamento humano no nordeste de Mato Grosso do Sul. Campo Grande: Life, 2012.

MARTINS, G. R.; KASHIMOTO, E. M.; TATUMI, S. H. Datações arqueológicas em Mato Grosso do Sul. Revista do Musen de Arqueologia e Etnologia, São Paulo, n.9, 1999.

MELIÁ, B.; SAUL, M. V. A.; MURARO, V. O Guarani. Uma bibliografia etnológica. Santo Ângelo: Fundação Pró-Memória/Fundames, 1987.

MENTZ RIBEIRO, P. A. A tradição ceramista Tupiguarani no sul do Brasil. In: PROUS, A.; LIMA, T. A. (Org.) Os ceramistas Tupiguarani. Brasília: Iphan, 2008.

MÉTRAUX, A. Ethnography of the Chaco. In: STEWARD, J. H. Handbook of South American Indians. Washington: Smithsonian Institution, 1946. v.1, p.197-370.

MIGLIACIO, M. C. A ocupação pré-colonial do Pantanal de Cáceres, Mato Grosso: uma leitura preliminar. 2000. Dissertação (Mestrado em Arqueologia) - Museu de Arqueologia e Etnologia, Universidade de São Paulo. São Paulo, 2000.

A ocupação indígena no Pantanal de Cáceres, Alto Paraguai - do período pré-colonial aos dias atuais. Revista do Musen Antropológico, Goiânia, v.5/6, n.1, p.213-50, 2000-2001. 
MIGLIACIO, M. C. O doméstico e o ritual: cotidiano Xaray no Alto Paraguai até o século XVI. 2006. Tese (Doutorado em Arqueologia) - Museu de Arqueologia e Etnologia, Universidade de São Paulo. São Paulo, 2006.

MILHEIRA, R. G. Território e estratégia de assentamento Guarani na planície sudoeste da Laguna dos Patos e Serra do Sudeste-RS. 2008. Dissertação (Mestrado em Arqueologia) - Museu de Arqueologia e Etnologia, Universidade de São Paulo. São Paulo, 2008.

MILLER, E. T. História da cultura indígena do alto-médio Guaporé. 1983. Dissertação (Mestrado em História) - Pontifícia Universidade Católica. Porto Alegre, 1983.

MONTEIRO, J. M. Os Guarani e a história do Brasil meridional. In: CARNEIRO DA CUNHA, M. (Org.) História dos indios no Brasil. São Paulo: Companhia das Letras, 1992.

Negros da terra. São Paulo: Companhia das Letras, 1994.

MORAIS, J. L. A utilização dos afloramentos litológicos pelo homem pré-histórico brasileiro: análise do tratamento da matéria-prima. São Paulo: Fundo de Pesquisas do Museu Paulista, 1983.

. Arqueologia da região Sudeste. Revista USP, São Paulo, v.44, p.194-217, dez./jan./fev. 1999-2000.

NEVES, E. G. Arqueologia, história indígena e o registro etnográfico. Revista do Museu de Arqueologia e Etnologia, São Paulo, Suplemento 3, p.319-30, 1999a.

. Changing perspectives in Amazonian archaeology. In: POLITIS, G.; ALBERTI, B. Archaeology in Latin America. London: Routledge, 1999b. p.216-43.

Paths in the dark waters: archaeology as indigenous history in the Upper Rio Negro Basin, northwest Amazon. 2000. Thesis (PhD. in Anthropology) - Indiana University. Bloomington, 2000.

Tradição oral e Arqueologia na história indígena no alto rio Negro. In: FORLINE, L. C.; MURIETA, R. S. S.; VIEIRA, I. C. G. Amazônia: além dos 500 anos. Belém: Museu Goeldi, 2006.

NOELLI, F. S. Sem tekohá não há tekó: em busca de um modelo etnoarqueológico da subsistência e da aldeia Guarani e sua aplicação a uma área de domínio no delta do Jacuí/RS. 1993. Dissertação (Mestrado em História) - Pontifícia Universidade Católica. Porto Alegre, 1993.

As hipóteses sobre os centros de origem e as rotas de expansão dos Tupi. Revista de Antropologia, São Paulo, v.39, n.2, p.7-53, 1996.

Repensando os rótulos e a história dos Jê no Sul do Brasil a partir de uma interpretação interdisciplinar. Revista do Museu de Arqueologia e Etnologia, São Paulo, Suplemento 3, p.285-302, 1999.

. A ocupação humana na região Sul do Brasil: arqueologia, debates e perspectivas - 1872-2000. Revista USP, São Paulo, v.44, p.218-69, 1999-2000.

La distribución geográfica de las evidencias aqueológicas Guaraní. Revista de Indias, Madrid, v.LXIV, n.230, 2004.

NOELLI, F. S.; BROCHADO, J. P. O cauim e as beberagens dos Guarani: equipamento, técnicas de preparação e consumo. Revista do Museu de Arqueologia e Etnologia, São Paulo, n. 8, p. 117-128, 1998. 
ORTIZ, G. Estado actual del conocimiento del denominado Complejo o Tradición cultural San Francisco, a 100 años de su descubrimiento. In: ORTIZ, G; VENTURA, B. (Ed.) La mitad verde del mundo andino. Investigaciones arqueológicas en la vertiente oriental de los Andes y las Tierras Bajas de Bolivia y Argentina. San Salvador de Jujuy: Universidad Nacional de Jujuy, 2003. p.23-71.

¿Pescadores, cazadores, recolectores pedemontanos? El caso de las sociedades de Tradición San Francisco (Prov. de Jujuy, Noroeste de Argentina). Cazadores Recolectores del Cono Sul, n.4, p.115-33, 2013.

PALLESTRINI, L. Sítio arqueológico da lagoa São Paulo: Presidente Epitácio/SP. Revista do Museu Paulista, São Paulo, v.25, p.381-410, 1984.

PALLESTRINI, L.; CHIARA, W. Indústria lítica de Camargo-76, Município de Pirajú, Estado de São Paulo. Revista do Museu Paulista, São Paulo, v.2, p.83-122, 1978.

PÄRSSINEN, M. Quando começou, realmente, a expansão Guarani em direção às Serras Andinas Orientais. Revista de Arqueologia, São Paulo, v.18, p.51-66, 2005.

PEIXOTO, J. L. S. Populações indígenas de tradição Tupiguarani no Pantanal Sul-mato-grossense. Revista do Museu de Arqueologia e Etnologia, São Paulo, n.8, p.71-86, 1998.

A ocupação dos povos indígenas pré-coloniais nos grandes lagos do Pantanal Sul-mato-grossense. 2003. Tese (Doutorado em História) - Pontifícia Universidade Católica. Porto Alegre, 2003.

PEIXOTO, J. L. S.; BEZERRA, M. A. O. Os povos ceramistas que ocuparam a planície aluvial antes da conquista europeia. In: IV SIMPÓSIO SOBRE RECURSOS NATURAIS E SOCIOECONÔMICOS DO PANTANAL. 2004, Corumbá. Anais... Corumbá: Embrapa, 2004.

PIEDADE, S. C.; SOARES, A. L. Considerações sobre um enterramento Guarani: alterações e hipóteses etno-históricas. Revista do Museu de Arqueologia e Etnologia, São Paulo, n.10, p.331-68, 2000.

POLITIS, G. G.; BONOMO, M. La entidad arqueológica Goya-Malabrigo (Ríos Paraná y Uruguay) y su filiación Arawak. Revista de Arqueologia, São Paulo, v.25, n.1, p.10-46, 2012.

PÓVOA, M. B. Arqueologia dos Abrigos Cera, Aquidanana/MS: cultura material e inserção na paisagem. 2007. Dissertação (Mestrado em Arqueologia) - Museu de Arqueologia e Etnologia, Universidade de São Paulo. São Paulo, 2007.

PREZIA, B. A. Os indigenas do planalto paulista nas crônicas seiscentistas e setecentistas. São Paulo: Humanitas; FFLCH-USP, 2000.

PROUS, A. Arqueologia brasileira. Brasília: UnB, 1992.

As primeiras populações do Estado de Minas Gerais. In: TENÓRIO, M.C. Pré-história da Terra Brasilis. Rio de Janeiro: UFRJ, 1999.

RIBEIRO, D. Kadiwéu. Petrópolis: Vozes, 1980.

Os indios e a civilização. Petrópolis: Vozes, 1986.

RIBEIRO, E. R. Macro-Jê. In: BROWN, K. (Ed.) Encyclopedia of language \& linguistics. 2.ed. Oxford: Elsivier, 2006. p.422-6. 
RIESTER, J. Arqueologia y arte rupestre en el oriente boliviano. Cochabamba; La Paz: Editorial Los Amigos del Libro, 1981.

RIVASSEU, E. A vida dos indios Guaicurus. São Paulo: Nacional, 1936.

ROBRAHN-GONZALEZ, E. M. Os grupos ceramistas pré-coloniais do Centro-Oeste brasileiro. Revista do Museu de Arqueologia e Etnologia, São Paulo, n.6, p.83-121, 1996.

RODRIGUES, A. D. A classificação do tronco linguístico Tupi. Revista de Antropologia, São Paulo, v. 12, p. 99-104, 1964.

RODRIGUES DO PRADO, F. História dos indios cavaleiros ou da nação Guaicuru. Campo Grande: IHGMS, 2009.

RONDON, C. M. da S. Relatório dos trabalhos realizados de 1900-1906 pela Comissão de Linhas Telegráficas do Estado de Mato Grosso, apresentado às autoridades do Ministério da Guerra pelo Major de Engenharia Cândido Mariano da Silva Rondon, como chefe da Comissão. Rio de Janeiro: Imprensa Nacional, 1949.

ROUSE, I. The Tainos: rise \& decline of the people who greeted Columbus. New Haven; London: Yale University Press, 1992.

SANCHEZ-LABRADOR, J. El Paraguay Católico. Buenos Aires: Hermanos, 1910.

SCATAMACCHIA, M. C. M. A tradição policrômica no leste da América do Sul evidenciada pela ocupação Guarani e Tupinambá: fontes arqueológicas e etno-históricas. 1990. Tese (Doutorado em Antropologia) - Faculdade de Filosofia, Letras e Ciências Humanas, Universidade de São Paulo. São Paulo, 1990.

SCHADEN, E. Aspectos fundamentais da cultura Guarani. 3.ed. São Paulo: EPU; Edusp, 1974.

SCHMIDEL, U. Relato de la conquista del rio de la Plata y Paraguay: 1534-1555. Madrid: Alianza, 1986.

SCHMIDT, M. Hallazgos prehistóricos en Matto Grosso. Revista de la Sociedad Cientifica del Paraguay, Asunción, v.1, n.5, p.27-62, 1940a.

Nuevos hallazgos de grabados rupestres en Matto Grosso. Revista de la Sociedad Científica del Paraguay, Asunción, v.1, n.5, p.63-71, 1940 b.

Los Payaguá. Revista do Museu Paulista, São Paulo, v.III, p.128-269, 1949.

SCHMITZ, P. I. Arqueologia em Mato Grosso do Sul: dois projetos, dois resultados. Fronteiras, v.2, n.4, p.203-221, 1998.

Caçadores-coletores do Brasil Central. In: TENÓRIO, M. C. (Org.) Pré-história da Terra Brasilis. Rio de Janeiro: UFRJ, 1999a. p.75-88.

Caçadores-coletores-pescadores do Pantanal de Mato Grosso do Sul. In: TENÓRIO, M. C. (Org.) Pré-história da Terra Brasilis. Rio de Janeiro: UFRJ, 1999b. p.149-57.

SCHMITZ, P. I. et al. Aterros indígenas no Pantanal de Mato Grosso do Sul. Pesquisas, São Leopoldo, v.54, 1998.

SCHMITZ, P. I.; BROCHADO, J. J. P. Datos para una secuencia cultural del Estado de Rio Grande do Sul, Brasil. Gabinete de Arqueologia, Porto Alegre, n.2, 1972.

SCHUCH, M. E. J. Xaray e Chané: índios frente à expansão espanhola e portuguesa 
no alto Paraguai. 1995. Dissertação (Mestrado em História) - Universidade do Vale do Rio dos Sinos. São Leopoldo, 1995.

STEINEN, K. V. D. Entre os aborigenas do Brasil Central. São Paulo: Departamento de Cultura, 1940.

SEPLAN. Atlas Multirreferencial do Estado de Mato Grosso do Sul. Campo Grande: Estado de Mato Grosso do Sul, 1990.

SILVA, F. A. Manifestações artísticas pré-históricas: um estudo descritivo-classificatório e interpretativo da arte rupestre de Serranópolis-Goiás. 1992. Dissertação (Mestrado em Antropologia) - Universidade Federal do Rio Grande do Sul. Porto Alegre, 1992.

SIQUEIRA JUNIOR, J. G. Arte e técnicas Kadiwéu. São Paulo: Imprensa Oficial; Fapesp, 1992.

SOARES, A. L. R. Revisitando a organização sociopolítica Guarani: pode-se fazer etnohistória e arqueologia? In: VII Jornadas Internacionales Sobre Las Missiones Jesuíticas, 1998, Chaco. Anais... Chaco, Instituto de Investigaciones Geohistoricas-Conicet/Faculdad de Humanidades-UNNE, p.567-82.

. Os horticultores Guarani: problemáticas, perspectivas e modelos. In: QUE-

VEDO, J. (Org.) Rio Grande do Sul: quatro séculos de história. Porto Alegre: Martins Livreiro, 1999.

Os horticultores Guaranis: modelos, problemáticas e perspectivas. Revista do CEPA, Santa Cruz do Sul, v.23, p.103-41, 2000.

. Arqueologia, história e etnografia: o denominador Guarani. Revista de Arqueologia, São Paulo, v.14/15, 2001-2002.

Contribuição para a Arqueologia Guarani: o estudo do sítio Röpke. 2004. Tese (Doutorado em Arqueologia) - Museu de Arqueologia e Etnologia, Universidade de São Paulo. São Paulo, 2004.

SOUSA, N. M. de. A redução de Nuestra Señora de la Fe no Itatim: entre a cruz e a espada. 2002. Dissertação (Mestrado em História) - Universidade Federal de Mato Grosso do Sul. Dourados, 2002.

SUSNIK, B. Material arqueológico del área alto-Paraguayense. Boletín de la Sociedad Cientifica del Paraguay y del Museo etnográfico Andrés Barbero, Assinción, v.3, p.81$103,1959$.

El indio colonial del Paraguay. Assunción: Museo Etnográfico Andres Barbero, 1971 .

Barbero, 1984.

Guía del Museo: Etnografia Paraguaya. Asunción: Museo Etnográfico Andrés

TAUNAY, A. Scenas de Viagem. Rio de Janeiro: Typographia Americana, 1868.

. Relatos monçoeiros. Belo Horizonte: Itatiaia, 1981.

A retirada da Laguna. São Paulo: Companhia das Letras, 1997.

URBAN, G. A história da cultura brasileira segundo as línguas nativas. In: CARNEIRO DA CUNHA, M. (Org.) História dos indios no Brasil. São Paulo: Companhia das Letras, 1992.

VILHENA-VIALOU, A. Tecno-tipologia das indústrias líticas do sítio Almeida em seu quadro natural, arqueo-etnológico e regional. São Paulo: Museu Paulista, 1980. 
VIlHenA-Vialou, A. Pré-história do Mato Grosso. São Paulo: Edusp, 2005. v.1: "Santa Elina".

. Pré-história do Mato Grosso. São Paulo: Edusp, 2006. v.2: “Cidade de Pedra”.

VIVEIROS DE CASTRO, E. Comentário ao artigo de Francisco Silva Noelli. Revista de Arqueologia, São Paulo, v. 39, n. 2, p. 55-60, 1996.

WEBER, A. Os Eyiguayegui-Mbayá-Guaicuru: encontros e desencontros com os luso-brasileiros na capitania do Mato Grosso. 2002. Dissertação (Mestrado em História) - Universidade Federal de Mato Grosso do Sul. Dourados, 2002.

WILLEY, G. R. An introduction to American Archaeology. Englewood Cliffs: Prentice-Hall, 1971. v.2: "South America".

WÜST, I. Continuidade e mudança: para interpretação dos grupos pré-coloniais na bacia do rio Vermelho, Mato Grosso. 1990. Tese (Doutorado em Antropologia) - Faculdade de Filosofia, Letras e Ciências Humanas, Universidade de São Paulo. São Paulo, 1990.

Contribuições arqueológicas, etnoarqueológicas e etno-históricas para o estudo dos grupos tribais do Brasil Central: o caso Bororo. Revista do Museu de Arqueologia e Etnologia, São Paulo, n.2, p.13-26, 1992.

Etnicidade e tradições ceramistas: algumas reflexões a partir das antigas aldeias Bororo do Mato Grosso. Revista do Musen de Arqueologia e Etnologia, São Paulo, Suplemento 3, p.303-18, 1999.

WÜST, I.; VAZ, L. J. Grafismos de ação no alto São Francisco, sudeste do Mato Grosso. Revista do Museu Antropológico, Goiânia, v.2. n.1, p.47-88, 1998.

RESUMO - O artigo apresenta uma síntese dos dados arqueológicos sobre o Pantanal e o seu entorno, principalmente em Mato Grosso e Mato Grosso do Sul. Elaborado com base na noção de arqueologia como história indígena de longa duração, o artigo considera as trajetórias de estabelecimento e consolidação territorial da ocupação indígena regional, os processos de formação da configuração etnográfica encontrada pelos europeus e os impactos do colonialismo. O principal objetivo consiste em mostrar que a diversidade cultural característica do cenário etnográfico pantaneiro está associada à dinâmica histórica e cultural da ocupação indígena desde períodos anteriores à chegada dos conquistadores e colonizadores de origem europeia.

PALAVRAS-CHAVE: Arqueologia, História indígena, Pantanal.

ABSTRACT - The article presents an overview of the archaeological data on the Pantanal and its surrounding areas, mainly in Mato Grosso and Mato Grosso do Sul. Prepared based on the notion of archeology as long term indigenous history, the article considers the trajectories of territorial establishment and consolidation of the regional indigenous occupation, the formation processes of ethnographic setting found by Europeans and the impact of colonialism. The main objective is to show that cultural diversity charac- 
teristic of the Pantanal ethnographic scenario is associated with historical and cultural dynamics of indigenous occupation from periods prior to the arrival of the conquistadors and settlers of European origin.

KEYWORDS: Archaeology, Indigenous history, Pantanal.

Eduardo Bespalez é doutor em Arqueologia pelo Museu de Arqueologia e Etnologia da Universidade de São Paulo; professor do Departamento de Arqueologia da Universidade Federal de Rondônia. @ - eduardo.bespalez@unir.br

Recebido em 20.2.2015 e aceito em 2.3.2015.

${ }^{\text {I }}$ Departamento de Arqueologia, Universidade Federal de Rondônia, Porto Velho/RO, Brasil. 